\title{
Shell we cook it? An experimental approach to the microarchaeological record of shellfish roasting
}

\author{
Vera Aldeias $^{1,2}$ (D) - Shira Gur-Arieh ${ }^{3} \cdot$ Raquel Maria $^{1}$ - Patricia Monteiro ${ }^{2}$. \\ Pedro Cura ${ }^{4}$
}

Received: 30 May 2016 / Accepted: 6 October 2016/Published online: 20 October 2016

(C) The Author(s) 2016. This article is published with open access at Springerlink.com

\begin{abstract}
In this paper, we investigate the microarchaeological traces and archaeological visibility of shellfish cooking activities through a series of experimental procedures with direct roasting using wood-fueled fires and controlled heating in a muffle furnace. An interdisciplinary geoarchaeological approach, combining micromorphology, FTIR (in transmission and ATR collection modes), TGA and XRD, was used to establish a baseline on the mineralogical transformation of heated shells from aragonite to calcite and diagnostic sedimentary traces produced by roasting fire features. Our experimental design focused on three main types of roasting procedures: the construction of shallow depressions with heated rocks (pebble cuvette experiments), placing shellfish on top of hot embers and ashes (fire below experiment), and by kindling short-lived fires on top of shellfish (fire above experiments). Our results suggest that similar shellfish roasting procedures will largely create microstratigraphic signatures of anthropogenically reworked combusted material spatially "disconnected" from the actual combustion locus. The construction of shallow earth ovens might entail an increased
\end{abstract}

Electronic supplementary material The online version of this article (doi:10.1007/s12520-016-0413-1) contains supplementary material, which is available to authorized users.

Vera Aldeias

vera aldeias@eva.mpg.de

1 Department of Human Evolution, Max Planck Institute for Evolutionary Anthropology, Leipzig, Germany

2 Interdisciplinary Center for Archaeology and Evolution of Human Behavior (ICArEHB), Universidade do Algarve, Faro, Portugal

3 Max Planck Research Group on Plant Foods in Hominin Dietary Ecology, Max Planck Institute for Evolutionary Anthropology, Leipzig, Germany

4 Museu de Arte Pré-histórica de Mação, Mação, Portugal archaeological visibility, and some diagnostic signatures of in situ hearths can be obtained by fire below roasting activities. We also show that macroscopic visual modifications and mineralogical characterization of discarded shellfish might be indicative of specific cooking activities versus secondary burning.

Keywords Experimental archaeology · Cooking · Shellfish roasting $\cdot$ Fire $\cdot$ FTIR $\cdot$ Soil Micromorphology

\section{Introduction}

The role of marine and coastal diets in human adaptation has been increasingly emphasized in recent years. Consumption of marine resources among early anatomically modern humans in Africa is one of the traits commonly associated with the emergence of modern behavior (Marean et al. 2007; McBrearty and Brooks 2000). Others argue that some reliance on shellfish exploitation can already be observed in Neanderthal adaptive strategies (Cortés-Sánchez et al. 2011; Hardy and Moncel 2011) and that submersion of Pleistocene coastal sites may significantly bias our views on the exact role played by coastal resources in early hominin adaptations (Bailey and Flemming 2008). Independently of early uses of marine environments, the current archaeological evidence in several continents attests to a clear shift during the Holocene with intensified exploitation of coastal and estuarine resources (Andersen 2000; Bailey and Milner 2002; Balbo et al. 2011; Habu et al. 2011; Lombardo et al. 2013; Sandweiss et al. 1998; Waselkov 1987). In Europe, large Mesolithic shell middens and mounds are widespread along coastal and paleoestuarine margins, with increased population dependence on marine diets evident by the high $\delta 15 \mathrm{~N}$ values of Mesolithic individuals (Milner et al. 2007; Peyroteo Stjerna 2016; Richards and 
Hedges 1999; Richards and Schulting 2006; Richards et al. 2003).

Although increased evidence for shellfish consumption is now available, archaeological data on human shellfish processing behaviors is still lacking. Humans can directly ingest raw shellfish, and, indeed even today, there are several examples of consumption of uncooked mollusks. Ethnographic and ethnohistoric descriptions provide examples of raw opening of bivalves by cracking uncooked shells or using broken shells as knifes to prompt open the closed valves (e.g., McGee and Hewitt 1898 cited in Waselkov 1987). However, heat-processed mollusks are recognized to yield higher caloric values and decrease dietary risks. One of the main challenges is how to identify shellfish cooking activities in the archaeological record. Most ethnographic observations of shellfish gatherers do show the prevalence of some sort of processing through cooking (namely roasting or boiling). By exposing the fresh shellfish to heat, mollusk valves open easily, hence quickly providing access to the edible portion of the mollusk. Since either roasting or boiling entails the preparation of several specimens at once, cooking is also a substantially more cost efficient way of processing shellfish than the time consuming task of cracking each valve individually (Waselkov 1987). Questions regarding the time frame in which mollusk cooking practices started to be commonly employed by humans and differences in cooking techniques in various archaeological contexts are of great importance to our understanding of human subsistence practice and adaptation. Yet in order to answer such questions, we first need to be able to identify mollusk cooking practices in the archaeological record.

One cooking technique is boiling, which employs some type of water retaining recipient, typically ceramic containers, though other perishable materials, such as animal skins or baskets, can be used (Speth 2015). Through boiling, the shellfish is not in direct contact with fire and relatively low temperatures just above the boiling point $\left(100^{\circ} \mathrm{C}\right)$ are enough to cook them. Another widespread cooking technique is roasting. Direct roasting of shellfish on fires without the resource of containers is commonly described ethnographically and arguably a better analogue for pre-ceramic communities such as those from Mesolithic Europe. Several ethnographic observations report on techniques of roasting/grilling, which can be subdivided into three main types: (1) cooking directly above hot fires by placing shellfish on top of embers or ashes; (2) using shallow depressions and heated rocks in earth ovens; or (3) by roasting shellfish underneath short-lived fires (Meehan 1977; Meehan 1982; Speth 2015; Thoms 2008; Waselkov 1987). In her detailed ethnographic study, for instance, Meehan describes the expedient technology used by the Anbarra Australian aborigines to cook shellfish underneath fires:

"A clean area of sand (...) is selected, cleared of rubbish and made smooth. The shells are then stacked carefully against each other with their lips in the sand, hinges uppermost. (...) Small sticks and dead grass are placed on top of this phalanx of shells and ignited. (...) These fires are designed to be fast and hot and usually burn for a few minutes only. Sizzling and 'plopping' noises indicate that the shells are open and that the 'milk' or juices are escaping. What is left of the fire is immediately removed and the uppermost parts of the shells are swept clean with a bunch of fresh green leaves. The shells are then removed from their cooking position, placed on a pile of fresh green leaves until they cool, and are then eaten. A few shells usually get tossed around the hearth but they are normally left for the time being in discrete piles where they have been consumed, many pairs of valves remaining attached by gristle." (Meehan 1982 p. 86-87).

These fires were often done directly in the beach near the collecting sites (Meehan 1982). What seems to be characteristic from such ethnographic and ethnohistoric observations is the ephemeral duration of such cooking events, often lasting just a few minutes and requiring little preparation of the cooking area (Waselkov 1987). We can question, therefore, what would be the archaeological visibility of such expedient procedures, even if they were performed at the main habitation site. One expected evidence would be visual and/or compositional alteration of burned shells. Depending on the temperature range and degree of shell surface exposure to fire, thermal alteration can result in visible physical (crazing, cracking, etc.) and color modifications (d'Errico et al. 2013; Godino et al. 2011; March 1999a; March et al. 2014; Villagran 2014a; Villagran et al. 2011a). More pronounce changes can occur at the molecular level due to temperature induced mineralogical transformations of calcium carbonate polymorphs (Gaffey et al. 1991; Toffolo and Boaretto 2014; Weiner 2010; Yoshioka and Kitano 1985). Such transformation depends on the original bivalve shell mineralogy, which is most commonly aragonite, with some species having calcite or a mixture of calcite and aragonite in their shells (Addadi et al. 2006; Lowenstam and Weiner 1989; Weiner 2010). Since aragonite is metastable at earth surface pressures, aragonite to calcite transformation can be a useful proxy to reconstruct temperatures of archaeological hearth contexts (Godino et al. 2011; Mentzer 2014; Villagran 2014a). Another possible evidence for shellfish cooking would be the identification of sediments and artifact dispersion produced by these activities. Previous studies have investigated the effects of heating shellfish and experimental fires in shell midden contexts (e.g., March 1999a; March et al. 2014; Villagran 2014a, 2014b; Villagran et al. 2011a), yet our understanding of the microstratigraphic signatures (depositional and taphonomic) of shellfish roasting activities is still limited.

Here, we report on a series of experimental fires targeting shellfish roasting activities and controlled heating of selected mollusks, specifically, the common cockle (Cerastoderma edule) and peppery furrow (Scrapularia plana). Field cooking experiments were complemented by soil micromorphology, 
Fourier transform infrared spectroscopy (FTIR), X-ray diffraction (XRD), thermogravimetric analysis (TGA), and charcoal analyses. The goals of this paper can be described as twofold: on one hand to gather data on temperatures reached during shellfish roasting procedures and their possible impact on the threshold for mineral transformation of $\mathrm{CaCO}_{3}$ polymorphs (aragonite $>$ calcite) in biogenic valves, and, on the other hand, to explore the microstratigraphic and discard signatures associated with shellfish roasting in pre-pottery contexts. These experiments add to the growing research on microarchaeological experimentation references and explore the role of sediments and taphonomic analyses to address past human behavior.

\section{Materials and methods}

\section{Experimental design}

As mentioned above, for the experiments reported here, we selected two types of shellfish: the common cockle (from here onwards designated as cockle) and peppery furrow, since both bivalve species have shells exclusively composed by aragonite (Peacock 2009; Santos et al. 2012)—see also SI for XRD analyses of specimens used in the current study. Both species are commonly exploited in prehistoric and historic contexts, namely in European Mesolithic sites (Andersen 1989; Diniz and Arias 2012; Gutiérrez-Zugasti et al. 2011; Peacock 2009), and, in particular, in the Portuguese Mesolithic shell mounds (Aldeias and Bicho 2016) where one of the authors (VA) is currently conducting geoarchaeological oriented research. In order to address the microarchaeological signatures of shellfish roasting activities, we have conducted both controlled heating of individual shells in a muffle and experiments with several ways of cooking using wood-fueled fires.

Controlled muffle experiments - for these experiments, a total of 56 individual fresh shells of cockle and peppery furrow were heated at several temperatures as shown in Table 1. The muffle was set to the desired temperature and, once that temperature was reached, ceramic crucibles containing the samples were placed inside and left for durations of either 5 or $20 \mathrm{~min}$. The heated crucibles were then taken out and the heated shellfish specimens wrapped in foil. These heating times were chosen to mimic two extremes: a duration of $5 \mathrm{~min}$ at temperatures normally reached during wood fires is sufficient to open the bivalves and cook the flesh, whereas longer exposures of $20 \mathrm{~min}$ often result on the burning of the mollusks making them uneatable (i.e., burned). Note that near the threshold for mineral transformation, smaller temperature intervals of $50{ }^{\circ} \mathrm{C}$ and only short heating times $(5 \mathrm{~min})$ were applied in order to investigate the exact threshold associated with aragonite-calcite transformation for each shellfish type (Table 1).
Fire cooking experiments - the goal of these experimentations was to investigate microstratigraphic signatures and mineralogical changes produced through different ways of roasting shellfish without the use of containers. We used three main experimental settings (see Fig. 1 and Table 2 for details), all of which employed Pinus pinaster wood or needles as fuel (see below). Experimental names are designated by the letter "C" for pebble cuvette type of experiments, "Fa" for experiments with fire above the shellfish, and " $\mathrm{Fb}$ " for the experiment with fire bellow the shellfish; each of these designations are followed by a sequential number and the type of shellfish used is indicated in parenthesis (either cockle or peppery furrow, $\mathrm{Ck}$ and $\mathrm{PF}$ respectively). Therefore, experiment $\mathrm{Fa} 1(\mathrm{Ck})$ corresponds to the first experiment with fire above using cockles.

Experimental fires with a pebble cuvette were conducted by excavating a shallow basin-depression (on average $\sim 15 \mathrm{~cm}$ deep at its center) that was subsequently coated with quartzite and quartz pebbles. A fire was then lit on top of the pebbles and was left to burn for some time (see Table 2). Once the flame reduced, we removed all the fire residues (embers, ashes, and charcoals) and added the shellfish directly on top of the now hot stones. In one experiment, $\mathrm{C} 1 \mathrm{Ck}$ ), the shellfish was immediately covered with sand, creating an anaerobic environment, and left cooking for $35 \mathrm{~min}$. This experiment was performed only once since the shellfish cooked this way were covered in sand and hardly edible. In all other pebble cuvette experiments (C2 and $\mathrm{C} 3$ ), the shellfish were cooked in aerobic environment by lightly covering the surface of the cuvette structure surface with animal skins. A total of six pebble cuvette repetitions were done, and, on average, the shellfish were left inside this structure for $11 \mathrm{~min}$. This cooking technique can be described as an earth stone oven, and similar types of cook stone technology are described ethnographically (see, for instance, Thoms 2008).

The experiment performed with fire below $(\mathrm{Fb})$ was conducted by lighting a pine fuel fire and let it reduce to embers. Once no more flames were observed, the charcoal and smoldering wood logs were gently spread out in order to create a small contained area in the center of the fire to which cockles were added directly on top of the hot embers and ash (Fig. 1). After $20 \mathrm{~min}$, one could directly collect the shells and eat the mollusks. A similar type of cooking was described to be routinely used by indigenous societies in North and South America (Waselkov 1987 and references cited therein).

Finally, several experiments were conducted with fire above $(\mathrm{Fa})$. These experiments were performed by first organizing the shellfish on a surface with their umbos down (which minimizes the fall of the overlying fire residues when the bivalve opens, and follows ethnographic descriptions done by Meehan 1977, 1982). Subsequently, fuel was added to the top of the shellfish and the fire was lit. Fire events tended to be fast, lasting between 3 and $17 \mathrm{~min}$. For these experiments, we used three different types of fuels: 
Table 1 Macroscopic and FTIR (transmission and ATR) mineral transformations of peppery furrow and cockle shells from controlled muffle experiments heated for $5 \mathrm{~min}$ at different temperatures

\begin{tabular}{|c|c|c|c|c|c|c|c|}
\hline \multirow{2}{*}{$\begin{array}{l}\text { Temp. } \\
\left({ }^{\circ} \mathrm{C}\right)\end{array}$} & \multirow{2}{*}{$\begin{array}{l}\text { No. of } \\
\text { shells }\end{array}$} & \multicolumn{3}{|c|}{ Peppery furrow (PF) } & \multicolumn{3}{|l|}{ Cockle (Ck) } \\
\hline & & FTIR & FTIR-ATR & Macroscopic observations & FTIR & FTIR-ATR & Macroscopic observations \\
\hline 100 & 3 & Aragonite & Aragonite & No visible changes & Aragonite & Aragonite & No visible changes \\
\hline 200 & 2 & Aragonite & Aragonite & No visible changes & Aragonite & Aragonite & No visible changes \\
\hline 250 & 2 & Aragonite & Aragonite & $\begin{array}{l}\text { Darkening (brownish) exter- } \\
\text { nal surface of valve with } \\
\text { small cracks }\end{array}$ & $\begin{array}{l}\text { Aragonite } \\
\text { transforming } \\
\text { to calcite }\end{array}$ & $\begin{array}{l}\text { Aragonite } \\
\text { transforming } \\
\text { to calcite }\end{array}$ & $\begin{array}{l}\text { Darkening (brownish) exter- } \\
\text { nal surface around the rim }\end{array}$ \\
\hline 350 & 2 & $\begin{array}{l}\text { Aragonite } \\
\text { transforming } \\
\text { to calcite }\end{array}$ & $\begin{array}{l}\text { Aragonite } \\
\text { transforming } \\
\text { to calcite }\end{array}$ & $\begin{array}{l}\text { Black external surface and } \\
\text { wider cracks }\end{array}$ & $\begin{array}{l}\text { Aragonite } \\
\text { transforming } \\
\text { to calcite }\end{array}$ & $\begin{array}{l}\text { Aragonite } \\
\text { transforming } \\
\text { to calcite }\end{array}$ & $\begin{array}{l}\text { Black external surface around } \\
\text { the rim }\end{array}$ \\
\hline 400 & 2 & Calcite & Calcite & $\begin{array}{l}\text { Black external surface with } \\
\text { minor scaling and friable } \\
\text { internal surface }\end{array}$ & - & - & - \\
\hline 450 & 2 & Calcite & Calcite & $\begin{array}{l}\text { Grayish with red stained rim } \\
\text { and extensive scaling in } \\
\text { external surface }\end{array}$ & $\begin{array}{l}\text { Calcite with } \\
\text { traces of } \\
\text { aragonite }\end{array}$ & $\begin{array}{l}\text { Calcite with } \\
\text { traces of } \\
\text { aragonite }\end{array}$ & Grayish with red stained rim \\
\hline 500 & 2 & - & - & - & Calcite & Calcite & Grayish with red stained rim \\
\hline 550 & 2 & Calcite & Calcite & Grayish with red stained rim & Calcite & Calcite & $\begin{array}{l}\text { Grayish with red stained rim, } \\
\text { with scaling both in the } \\
\text { internal and external } \\
\text { surfaces }\end{array}$ \\
\hline 700 & 2 & Calcite & Calcite & $\begin{array}{l}\text { Whitish external surface with } \\
\text { brown and red domains } \\
\text { towards the rim. Whitish } \\
\text { gray internal surface, } \\
\text { completely scaled, thinned } \\
\text { and cracked (with holes) }\end{array}$ & Calcite & Calcite & $\begin{array}{l}\text { Whitish with mild pitting in } \\
\text { the external surface. } \\
\text { Whitish internal surface } \\
\text { with some red domains, } \\
\text { crumbly, and scaling }\end{array}$ \\
\hline 900 & 2 & $\begin{array}{l}\text { Minor calcium } \\
\text { hydroxide }\end{array}$ & $\begin{array}{l}\text { Minor calcium } \\
\text { hydroxide }\end{array}$ & White powder & $\begin{array}{l}\text { Calcite and } \\
\text { calcium } \\
\text { hydroxide }\end{array}$ & $\begin{array}{l}\text { Calcite and } \\
\text { calcium } \\
\text { hydroxide }\end{array}$ & White powder \\
\hline
\end{tabular}

small pine wood twigs and logs (experimental subtypes Fa1 and $\mathrm{Fa} 2$ ), pine needles (Fa3 and $\mathrm{Fa} 4)$, and hot embers relocated to the top of the mollusks from a nearby pine wood fire ( $\mathrm{Fa} 5$ and $\mathrm{Fa} 6)$. These experiments (each repeated at least two times) follow roasting shellfish techniques similar to the ones of Aboriginal Australian communities describes by Meehan $(1977,1982)$.

During all of the experimental events, temperatures were systematically recorded at 1-min intervals with a PCE-T390 contact thermometer device attached to several k-type thermocouple probes $(\mathrm{B}+\mathrm{B}$ Thermo-Technik $\mathrm{GmbH}$, Donaues chingen, Germany). For the pebble cuvette experiments, probes were positioned at three locations: directly underneath the base of the pebbles; in the center of the cuvette on top of the pebbles; at the center of the fire itself (that is, few $\mathrm{cm}$ above the pebbles surface) and, once the fire residues were taken out, this same probe was positioned at the center of the shellfish being cooked. In the fire above and fire below experiments, probes recorded the temperatures at three locations: the center of the shells (placed on the ground between the shells), directly on the fire itself (placed on top of the shells), and $\sim 2 \mathrm{~cm}$ below the surface.

\section{Sampling strategy and analytical methods}

Sampling strategy

After each fire cooking experiment, we collected several samples for laboratory analyses, namely cooked shells, bulk samples of charcoal and ashes. Intact blocks of sediments were collected from the center of some of the experimental fires for soil micromorphology analysis (see below).

\section{Analytical methods}

Fourier transform infrared spectrometry Infrared analyses were carried out in order to determine the mineralogical composition of shellfish and evaluate aragonite to calcite transformation due to exposure to high temperatures at ambient pressures (Jamieson 1953; Johannes and Puhan 1971; Yoshioka and Kitano 1985). Three shells were randomly selected from 
Fig. 1 Summary of the field cooking experiments performed and associated human actions involved for each experimental subtype

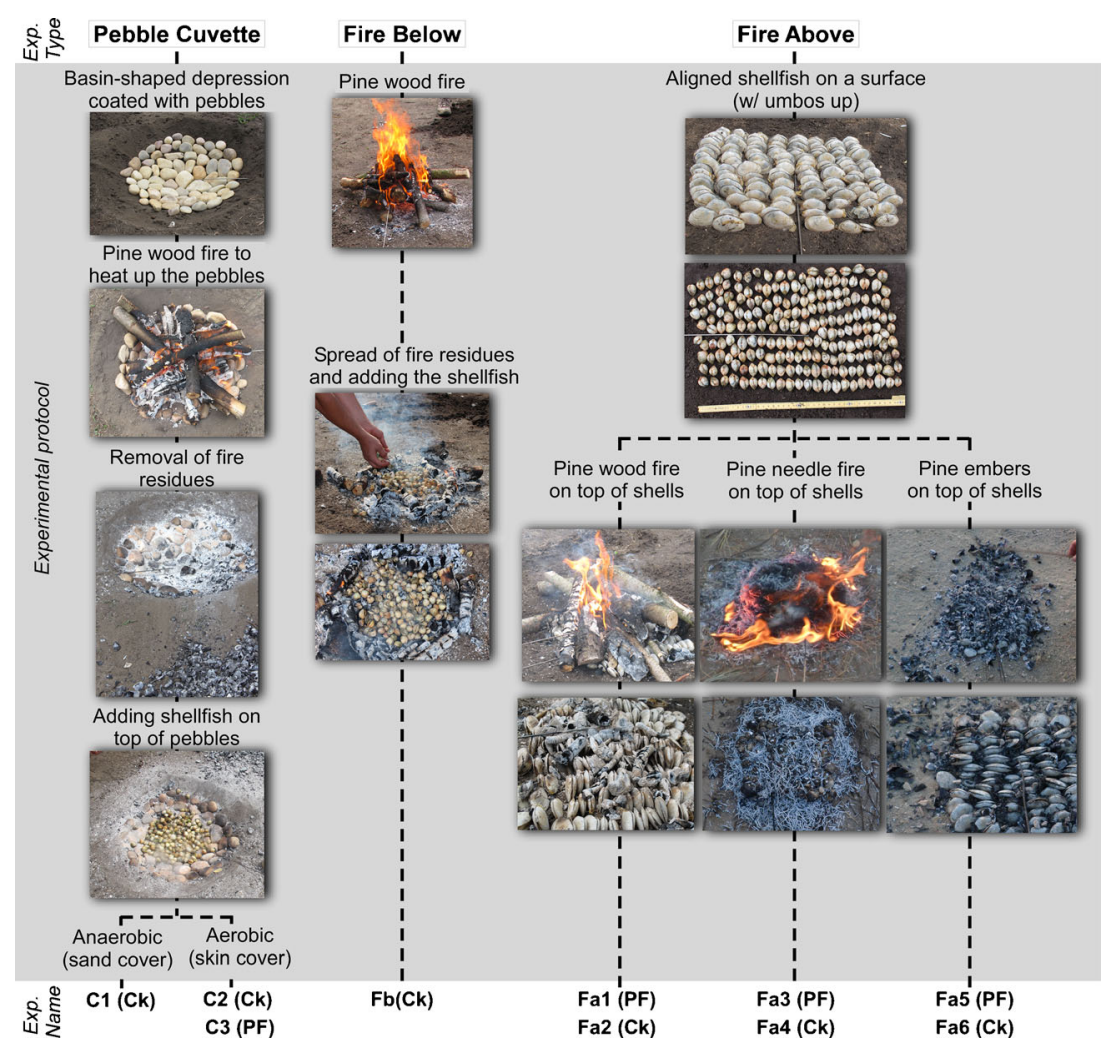

each type of fire cooking experiment. From the controlled muffle experiments, one shell from each species was analyzed from the different heating durations and temperatures performed. Infrared measurements were collected in transmission (FTIR) and attenuated total reflection (FTIR-ATR) mode. For transmission mode, about $0.3 \mathrm{mg}$ of sample was

Table 2 Summary of results from the fire cooking experiments

\begin{tabular}{|c|c|c|c|c|c|c|c|c|}
\hline Exp. & Exp. type & Exp. subtype & Rep. & $\begin{array}{l}\text { Duration fire } \\
\text { event (min.) }\end{array}$ & $\begin{array}{l}\text { Max. temp. } \\
\text { fire }\left({ }^{\circ} \mathrm{C}\right)\end{array}$ & $\begin{array}{l}\text { Cooking } \\
\text { duration (min.) }\end{array}$ & $\begin{array}{l}\text { Max. temp. near } \\
\text { shellfish }\left({ }^{\circ} \mathrm{C}\right)\end{array}$ & $\begin{array}{l}\text { Mineralogy of cooked } \\
\text { shells (FTIR) }{ }^{\mathrm{b}}\end{array}$ \\
\hline $\mathrm{C} 1(\mathrm{Ck})$ & \multirow[t]{3}{*}{$\begin{array}{l}\text { Pebble } \\
\text { cuvette }\end{array}$} & $\begin{array}{l}\text { Covered } \\
\text { with sand }\end{array}$ & $1 \times$ & 120 & 904 & 35 & 152 & $\mathrm{Ar}$ \\
\hline $\mathrm{C} 2(\mathrm{Ck})$ & & \multirow{2}{*}{$\begin{array}{l}\text { Covered } \\
\text { with skin }\end{array}$} & $3 \times$ & $124,31,40$ & $922,757,876$ & $10,8,9$ & $\mathrm{ND}, 100,123$ & $\mathrm{Ar}$ \\
\hline $\mathrm{C} 3(\mathrm{PF})$ & & & $2 \times$ & 60,75 & 852,820 & 8,9 & 101,167 & $\mathrm{Ar}$ \\
\hline $\mathrm{Fb}(\mathrm{Ck})$ & $\begin{array}{l}\text { Fire } \\
\quad \text { below }\end{array}$ & - & $1 \times$ & 35 & 933 & 20 & 72 & $\begin{array}{l}\operatorname{Ar} \text { (1shell), } \mathrm{Ar}>\mathrm{Ca} \\
\quad \text { (2shells) }\end{array}$ \\
\hline $\mathrm{Fa} 1(\mathrm{PF})$ & \multirow{6}{*}{$\begin{array}{l}\text { Fire } \\
\text { above }\end{array}$} & \multirow{2}{*}{$\begin{array}{l}\text { Pine wood } \\
\text { fuel }\end{array}$} & $2 \times$ & 17,16 & 781,633 & 11,11 & 87,82 & $\mathrm{Ar}$ \\
\hline $\mathrm{Fa} 2(\mathrm{Ck})$ & & & $3 \times$ & $15,9,9$ & $488,779,819$ & $15,9,9$ & $107,122,444^{\mathrm{a}}$ & $\begin{array}{l}\mathrm{Ar} \text { (1shell) } \mathrm{Ar}>\mathrm{Ca} \text { (1shell) } \\
\quad \mathrm{Ca}(1 \text { shell })\end{array}$ \\
\hline $\mathrm{Fa} 3(\mathrm{PF})$ & & \multirow{2}{*}{$\begin{array}{l}\text { Pine needles } \\
\quad \text { fuel }\end{array}$} & $2 \times$ & 17,17 & 754,675 & 17,17 & 77,78 & Ar (2shells) Ca (1shell) \\
\hline $\mathrm{Fa} 4(\mathrm{Ck})$ & & & $2 \times$ & 3,3 & 468,357 & 3,3 & 57,69 & $\operatorname{Ar}(2$ shells) Ca (1shell) \\
\hline $\mathrm{Fa} 5(\mathrm{PF})$ & & \multirow{2}{*}{$\begin{array}{l}\text { Pine Embers } \\
\text { fuel }\end{array}$} & $2 \times$ & 10,8 & 406,475 & 3,3 & 47,37 & $\mathrm{Ar}$ \\
\hline $\mathrm{Fa} 6(\mathrm{Ck})$ & & & $2 \times$ & 13,14 & 349,441 & 3,3 & $70,147^{\mathrm{a}}$ & $\mathrm{Ar}$ \\
\hline
\end{tabular}

Exp. experiment, Rep. number of repetitions, $N D$ no data, $\mathrm{Ar}$ aragonite, $\mathrm{Ca}$ calcite, $\mathrm{Ar}>\mathrm{Ca}$ aragonite transforming to calcite

${ }^{a}$ These two temperature readings (shown in italic) are related to a bad positioning of the thermocouple in direct contact with the fire/embers and should not be taken into account. In the case of the temperature of $444{ }^{\circ} \mathrm{C}$ in the third repetition of $\mathrm{Fa} 2(\mathrm{CK})$ experiment, the shellfish near these temperature readings were burned and uneatable

${ }^{\mathrm{b}}$ A total of three randomly selected shells were analyzed by FTIR transmission mode for each experiment 
homogenized in an agate mortar and pestle, then mixed with $\sim 40 \mathrm{mg}$ of IR grade $\mathrm{KBr}$ powder and pressed into a pellet using a manual hydraulic press (Wasserman). Spectra were recorded in transmission mode with an Agilent 660 FTIR Spectrometer (Agilent Technologies) with a DTGS detector, at $4 \mathrm{~cm}^{-1}$ resolution and averaging of 32 scans between 4000 and $400 \mathrm{~cm}^{-1}$ using Resolution Pro software (Agilent Technologies). Spectra obtained from FTIR-ATR mode were performed on ground samples using an Agilent 660 FTIR Spectrometer (Agilent Technologies) fitted with a detachable accessory GladiATR ${ }^{\mathrm{TM}}$ (Pike Technologies) with a diamond crystal. Spectra were recorded at $4 \mathrm{~cm}^{-1}$ resolution and averaging of 32 scans between 4000 and $400 \mathrm{~cm}^{-1}$. The obtained spectra were evaluated and compared with reference publications and libraries (Lafuente et al. 2015; Weiner 2010).

X-ray powder diffraction XRD analyses were carried out to determine the mineralogical composition of the two shellfish species and confirm that they were composed exclusively of aragonite. XRD patterns were recorded on a STOE STADI MP diffractometer (STOE\&Cie $\mathrm{GmbH}$ ) at room temperature using $\mathrm{Cu}-\mathrm{K} \alpha 1$ radiation (emission wavelength $1.54059 \AA$ ).

Thermogravimetric analysis TGA analysis was conducted on fresh shells of cockle and peppery furrow in order to determine the organic fraction through weight loss in the shell matrix. The shells were ground, placed in sealed aluminum crucible, and measured in a Netzsch F1 (Phoenix NetzschGerätebau $\mathrm{GmbH}$ ) with the following conditions: air flow (30 mL/min) with heating rates of $10 \mathrm{~K} / \mathrm{min}$ up to $800{ }^{\circ} \mathrm{C}$. For the buoyancy correction, a baseline was recorded using roughly $40 \mathrm{mg}$ of dry $\mathrm{Al}_{2} \mathrm{O}_{3}$ and subtracted from the sample measurements. Experiments were performed in triplicate sequentially in a room with $56 \%$ relative humidity.

Soil Micromorphology - intact blocks for soil micromorphology analyses were collected from the fire above and fire below field cooking experimentations. Given the large size of the components and removal of fire residue procedures, it was impractical to collect micromorphology samples from the center of pebble cuvette experiments. It is also important to note that in order to process these samples, we had to remove the organic flesh of the mollusks. The empty shells were then repositioned on the surface sediments, which implied movement from the original cooking placement. Consequently, no interpretations based on shell orientations or imbrications are made based on thin section analyses. The sampled sediment blocks were wrapped with soft paper and carefully tightened using plastic tape. Thin section preparation was performed by Spectrum Petrographics (Vancouver, WA, USA) by oven drying the samples for several days and then impregnating them with epoxy mixed with styrene and a catalyst. The indurated blocks were then cut, mounted to a $5 \times 7.5 \mathrm{~cm}$ glass, and grinded to a standard thickness of $30 \mu \mathrm{m}$. In addition,
Spectrum Petrographics also prepared smaller-sized $2.7 \times 4.6-\mathrm{cm}$ thin sections for individual shells heated in the controlled muffle experiments. All thin sections were analyzed under plane- and cross-polarized light (PPL and XPL, respectively) using an Olympus BX51 petrographic microscope at magnifications ranging from $\times 20$ to $\times 400$.

Charcoal analyses - analyses of wood charcoal focused on taphonomic alterations during the combustion of $P$. pinaster fuel in the fire cooking experiments. Samples were recovered by hand-picking charcoal fragments after each cooking event. A total of 50 charcoals were examined by randomly selecting five fragments from pebble cuvette $(\mathrm{C} 1$ and $\mathrm{C} 2)$, fire below $(\mathrm{Fb})$, fire above with pine wood ( $\mathrm{Fa} 1$ and $\mathrm{Fa} 2)$, and fire above with pine embers fuels ( $\mathrm{Fa} 5$ and $\mathrm{Fa} 6$ ). The combustion of pine needles does not produce suitable samples, and this experiment was therefore excluded from these analyses. Analyses of the conserved cellular structure and identification of taphonomic alterations were performed by examining each fragment under a microscope (Leica DM $2500 \mathrm{P}$ ) at $\times 100$ and $\times 200$ magnifications. Transversal $(\mathrm{T})$, longitudinal radial (R), and longitudinal tangential ( $\mathrm{Tg}$ ) sections were observed for each fragment and all the alterations observed recorded.

\section{Results}

\section{Controlled muffle experiments—visual and structural changes}

A summary of the visual and mineral transformations from the controlled muffle heated shells is shown in Table 1. Results of thin section analyses of selected heated shells are shown in Fig. 2. For both species, obvious alterations are visible at $550{ }^{\circ} \mathrm{C}$, even after very short heating episodes of $5 \mathrm{~min}$. These microscopic alterations are seen in the change from high birefringence (3rd order interference) colors associated with aragonite to duller interference colors, which are mineralogically associated with the complete transformation to calcite (see below). At higher temperatures of $700{ }^{\circ} \mathrm{C}$, the shells tend to present several macro and microscopic vertical cracks as well as parallel fissures. The latter tend to be well developed for the thinner peppery furrow specimens (Fig. 2).

Since no differences were observed between mineral transformations related to heating durations of 5 versus $20 \mathrm{~min}$, only the FTIR spectra associated with 5-min durations are presented here. Figure 3 also provides a comparison of spectra from FTIR transmission and FTIR-ATR, showing that these two collection modes produce similar results. Only a peak distortion and shift are observed for the FTIR-ATR spectra when compared with transmission spectra.

In respect to mineralogical transformations, results from unheated shells present FTIR spectra of aragonitic calcium carbonate $\left(\mathrm{CaCO}_{3}\right)$ similar to published data (Llave et al. 


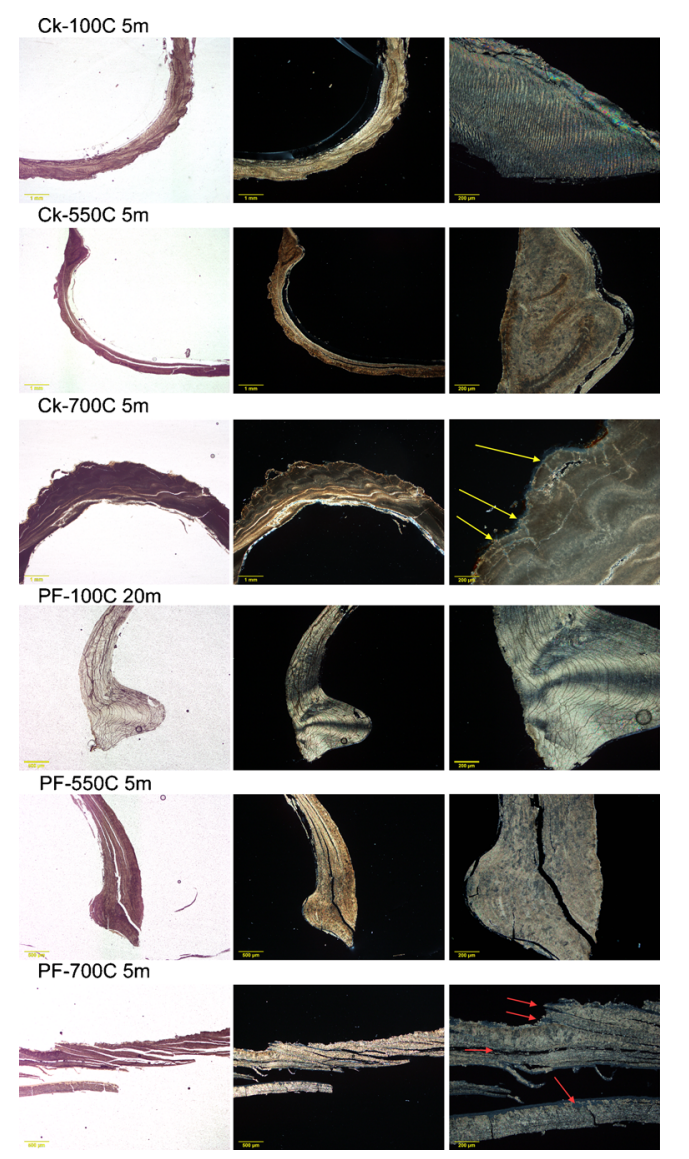

Fig. 2 Photomicrographs of muffle heated cockles $(C k)$ and peppery furrow $(P F)$ at different temperatures $\left(100,550\right.$, and $\left.700{ }^{\circ} \mathrm{C}\right)$ and heating durations (5 and $20 \mathrm{~min}$ ). Left: microphotographs in PPL, scale is $1 \mathrm{~mm}$; middle: microphotographs in XPL, scale is $1 \mathrm{~mm}$; and right: detailed microphotographs in XPL, scale is $200 \mu \mathrm{m}$. Note that at $100{ }^{\circ} \mathrm{C}$, both species have aragonitic shells expressed by extremely high birefringence even after $20 \mathrm{~min}$. Duller interference colors are seen at temperatures of $550{ }^{\circ} \mathrm{C}$, and at $700{ }^{\circ} \mathrm{C}$ several cracks are developed in cockles (yellow arrows) and common fissures in peppery furrow specimens (red arrows)

2006; Loftus et al. 2015; Weiner 2010). Despite some inconsistency in the literature on the exact positioning of aragonite and calcite peaks obtained by conventional FTIR methods (see, for instance, Andersen and Brecevic 1991), both FTIR spectra of the unheated samples present the typical vibrational modes of the $\mathrm{C}-\mathrm{O}$ band of carbonate ion $\left(\mathrm{CO}_{3}{ }^{2-}\right)$ for aragonite: the $v_{3}$ asymmetric stretch at $1475 \mathrm{~cm}^{-1}$, the $v_{1}$ symmetric stretch at $1082 \mathrm{~cm}^{-1}$, the $v_{2}$ out of plane bending at $860 \mathrm{~cm}^{-1}$ and the $v_{4}$ in plane bending doublet at 714 and $700 \mathrm{~cm}^{-1}$ (respectively, at $1465 \mathrm{~cm}^{-1}, 1082 \mathrm{~cm}^{-1}, 856$ and 712 and $700 \mathrm{~cm}^{-1}$ in ATR). With heating, the transformation of aragonite to calcite is visible by the appearance of the peak at $876 \mathrm{~cm}^{-1}$ (the $v_{2}$ out of plane bending for calcite) and the broadness of the peak at $1475 \mathrm{~cm}^{-1}$ - a stage designated here as "aragonite transforming to calcite". This transformation starts at different temperatures in the analyzed shells, specifically around $250{ }^{\circ} \mathrm{C}$ for cockle and around $350{ }^{\circ} \mathrm{C}$ for peppery furrow. Complete transformation to calcite occurs at $500{ }^{\circ} \mathrm{C}$ for cockle and $400{ }^{\circ} \mathrm{C}$ for peppery furrow, identified by the present of only the typical vibrational modes of the $\mathrm{C}-\mathrm{O}$ band of carbonate ion $\left(\mathrm{CO}_{3}{ }^{2-}\right)$ for calcite: the $v_{3}$ asymmetric stretch at $1427 \mathrm{~cm}^{-1}$, the $v_{2}$ out of plane bending at $876 \mathrm{~cm}^{-1}$, and the $v_{4}$ in plane bending at $714 \mathrm{~cm}^{-1}$ (respectively, at $1405 \mathrm{~cm}^{-1}, 874 \mathrm{~cm}^{-1}$, and $712 \mathrm{~cm}^{-1}$ in ATR).

It is interesting, therefore, to note that for cockles the transformation of aragonite into calcite starts at a lower temperature, but the complete transformation to pure calcite also takes longer to occur when compared to peppery furrow. Cockles heated to $450{ }^{\circ} \mathrm{C}$ present all the characteristics calcite peaks, but traces of aragonite are still visible by the presence of the additional peak at $860 \mathrm{~cm}^{-1}$ (in a stage designated here as "calcite with traces of aragonite"), whereas peppery furrow shows already a complete transformation to calcite at the same temperature (Fig. 3). At $900{ }^{\circ} \mathrm{C}$, a peak at $3640 \mathrm{~cm}^{-1}$ for both shellfish is also visible (see supplementary information). This peak can be attributed to the $\mathrm{O}-\mathrm{H}$ stretching of calcium hydroxide $\left(\mathrm{Ca}(\mathrm{OH})_{2}\right)$, produced by the heating of calcite that transformed into quicklime $(\mathrm{CaO})$ and $\mathrm{CO}_{2}$, which afterwards reacts with atmospheric moisture to form calcite and calcium hydroxide, $\mathrm{Ca}(\mathrm{OH})_{2}$ (Toffolo and Boaretto 2014).

\section{Fire cooking experiments}

\section{Roasting shellfish: temperatures and charcoal analyses}

Table 2 summarizes temperature values, durations of heating, and results of shell mineralogy from our field cooking experiments with roasting shellfish. Temperature changes associated with the three main types of experiments are illustrated in Fig. 4-all other temperature readings and charcoal analyses summary are available in the Supplementary Information.

Since our experimentation protocol was more actualistic in nature than highly controlled experimentation (see discussion in Lin et al. 2016), there is considerable variation in temperatures, even in repetitions of the same experimental type. It should be made clear that our goal with these repetitions was not to exactly replicate the same experimental setting but instead provide some degree of variation for each type of cooking events. Consequently, the range of experimental durations and temperatures achieved result from dependent variables not being maintained constant (such as input temperature variations within each wood fire, or amount of time the fuel was left to burn, etc.).

Overall, and despite fire temperature fluctuations, readings of the thermocouples positioned at the base of the shellfish being cooked never reach values above 
a

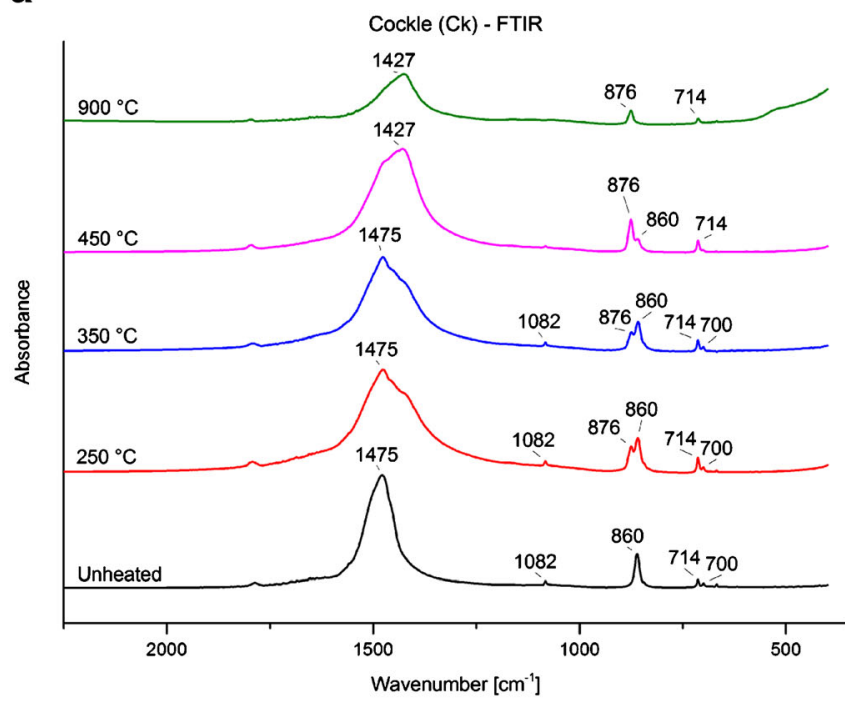

C

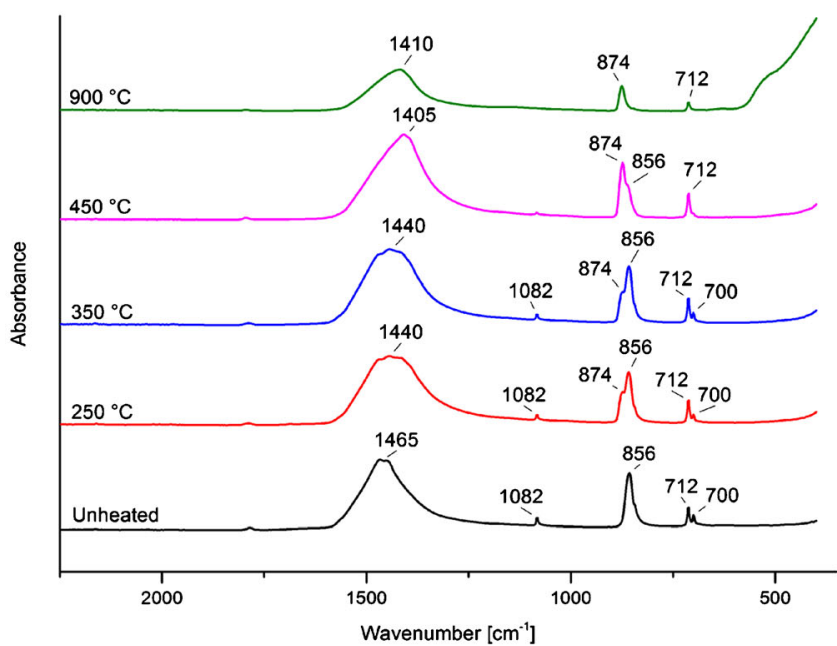

Fig. 3 Comparison between FTIR spectra of controlled muffle experiments for both shellfish types (cockles and peppery furrow), using FTIR transmission and ATR collection modes. (a, b) FTIR transmission spectra of cockle and peppery furrow shells; (c, d) FTIRATR spectra cockle and peppery furrow shells. Unheated samples present the major absorption peaks for aragonite: $1475 \mathrm{~cm}^{-1}, 1082 \mathrm{~cm}^{-1}$,

$170{ }^{\circ} \mathrm{C}$, with average maximum temperatures around the $95{ }^{\circ} \mathrm{C}$ (Table 2). The experiments with pebble cuvette systematically reached the highest and stable cooking temperatures, whereas the fast fires kindled with pine needles and embers had the lowest registered cooking temperatures at the base of the shellfish. Interestingly, it is in the fire below and fire above experiments that we observed macroscopic alterations of some shells, with brown to black colored domains and occasional fractures, namely in the uppermost exposed area of the shells' umbos section. Such modification seems to result from localized hot spots where the shellfish was in b

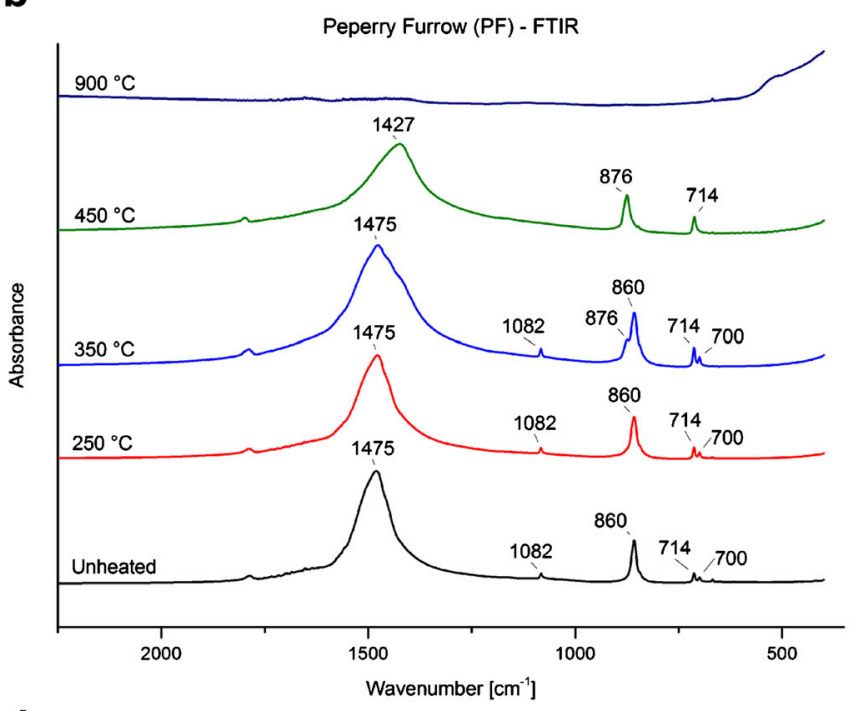

d

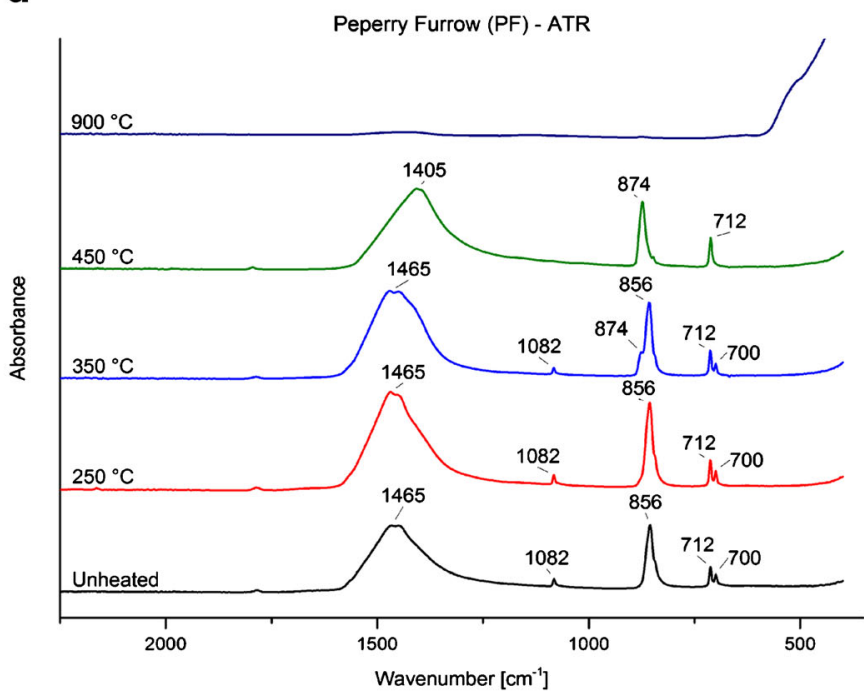

$860 \mathrm{~cm}^{-1}$ and the doublet at 714 and $700 \mathrm{~cm}^{-1}$ (respectively, at $1465 \mathrm{~cm}^{-1}, 1082 \mathrm{~cm}^{-1}, 856$ and 712 and $700 \mathrm{~cm}^{-1}$ in ATR). With heating the transformation of aragonite to calcite is visible by the appearance of the major absorptions peaks for calcite, specifically at $1427 \mathrm{~cm}^{-1}$, $876 \mathrm{~cm}^{-1}$, and $714 \mathrm{~cm}^{-1}$ (respectively, at $1405 \mathrm{~cm}^{-1}, 874 \mathrm{~cm}^{-1}$, and $712 \mathrm{~cm}^{-1}$ in ATR)

direct contact with flames. For instance, particularly in the experiments where pine wood fuel was used (Fa1 and $\mathrm{Fa} 2$ ), it was hard to maintain homogeneous temperatures throughout the entire shellfish surface, and in some areas, the direct contact with embers and burning wood was more accentuated than in others. It is important to note that temperature of the fires, which was in contact with the shells, was high enough to reach the threshold for aragonite to calcite transformation, and this has important implications for shell mineralogical transformations as it will be discussed below. In the pebble cuvette fires, the shellfish were not in direct 
a

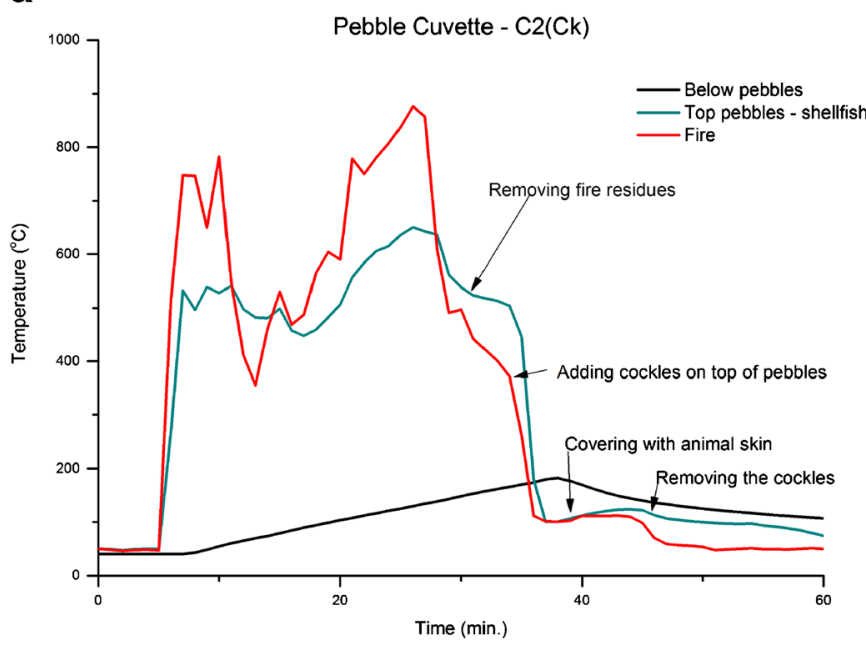

C

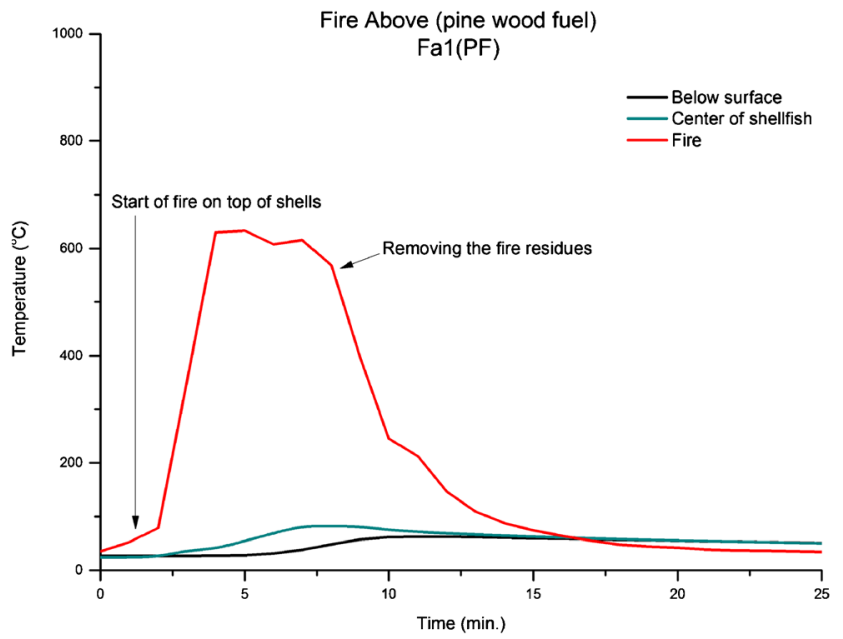

b

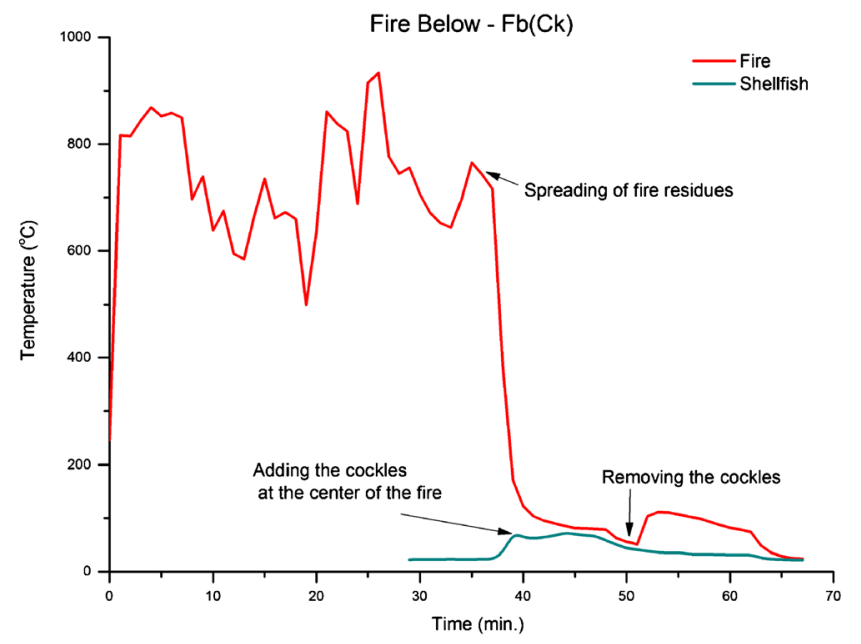

d

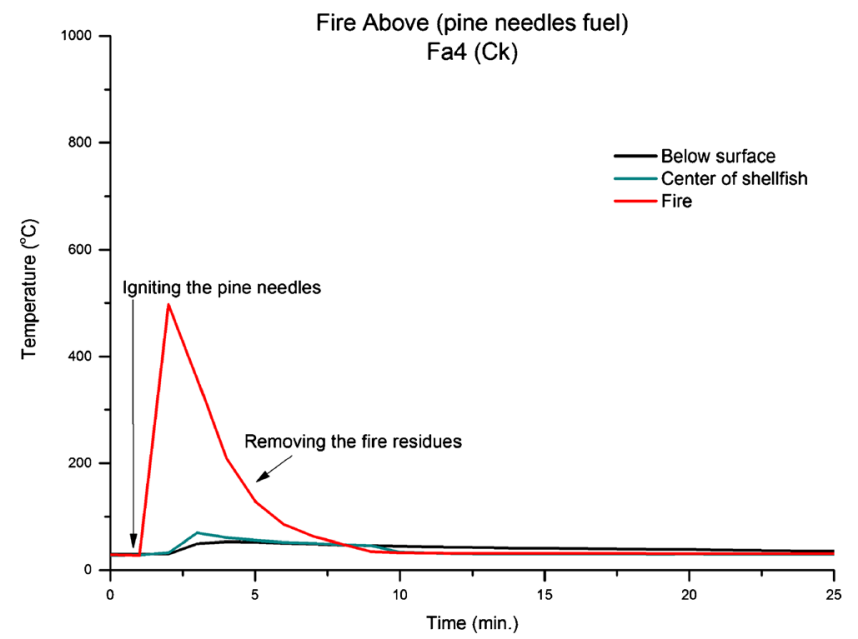

Fig. 4 Temperatures reached during field cooking experiments: a in a pebble cuvette experiment; $\mathbf{b}$ in the fire below experiment (no temperature reading available for the substrate underneath the fire); $\mathbf{c}, \mathbf{d}$ with pine wood fuel and pine needles fueled fire above

contact with fire, rather they were roasted on top of hot quartzite and quartz pebbles. Macroscopic color alterations were not observed in these shells, whereas the underlying pebbles did show significant color alterations, with a few pebbles fracturing with each experimental run (Fig. 5). In experiment $\mathrm{C} 2$ (Ck), we can observe that the pebble's surface reached a maximum temperature of $647{ }^{\circ} \mathrm{C}$ in response to fire temperatures commonly above $700{ }^{\circ} \mathrm{C}$ (Fig. 4a).

In terms of the amount of thermal alteration expected in the subsurface, our temperature readings just below the pebbles show that the amount of heat transfer to $\sim 2 \mathrm{~cm}$ depth is directly dependent on fire duration, with higher temperatures accumulating during longer events. We obtained maximum temperatures of 307,158 , and $182{ }^{\circ} \mathrm{C}$ for experiments lasting for 124,31 , and $40 \mathrm{~min}$, respectively (Table 2). This range of temperatures shows that higher substrate temperatures can easily be reached in events lasting longer than the fires performed here (Aldeias et al. 2016). Consequently, thermal alteration can occur in the sediments underlying a pebble cuvette cooking structure (March et al. 2014) and of course with fire below type of experiments. In contrast, substrate temperatures were constantly at values below $100{ }^{\circ} \mathrm{C}$ in fire above experiments (Fig. 4c, d), which entails little or no alteration of underlying deposits for similar fire types and durations.

In terms of the fires themselves, the combustion of $P$. pinaster fuels recorded substantial variance in maximum temperatures. These ranged from 922 to $488{ }^{\circ} \mathrm{C}$ (an average maximum temperatures of $797{ }^{\circ} \mathrm{C}$ ) in experiments with pebble cuvette, fire below, and fire above with pine wood and lower maximum average temperatures of $417^{\circ} \mathrm{C}$ in the fire above with pine embers (Table 2). This combustion process resulted in wood charcoal alterations in the form of vitrification and cracks (see Supplementary Information). 

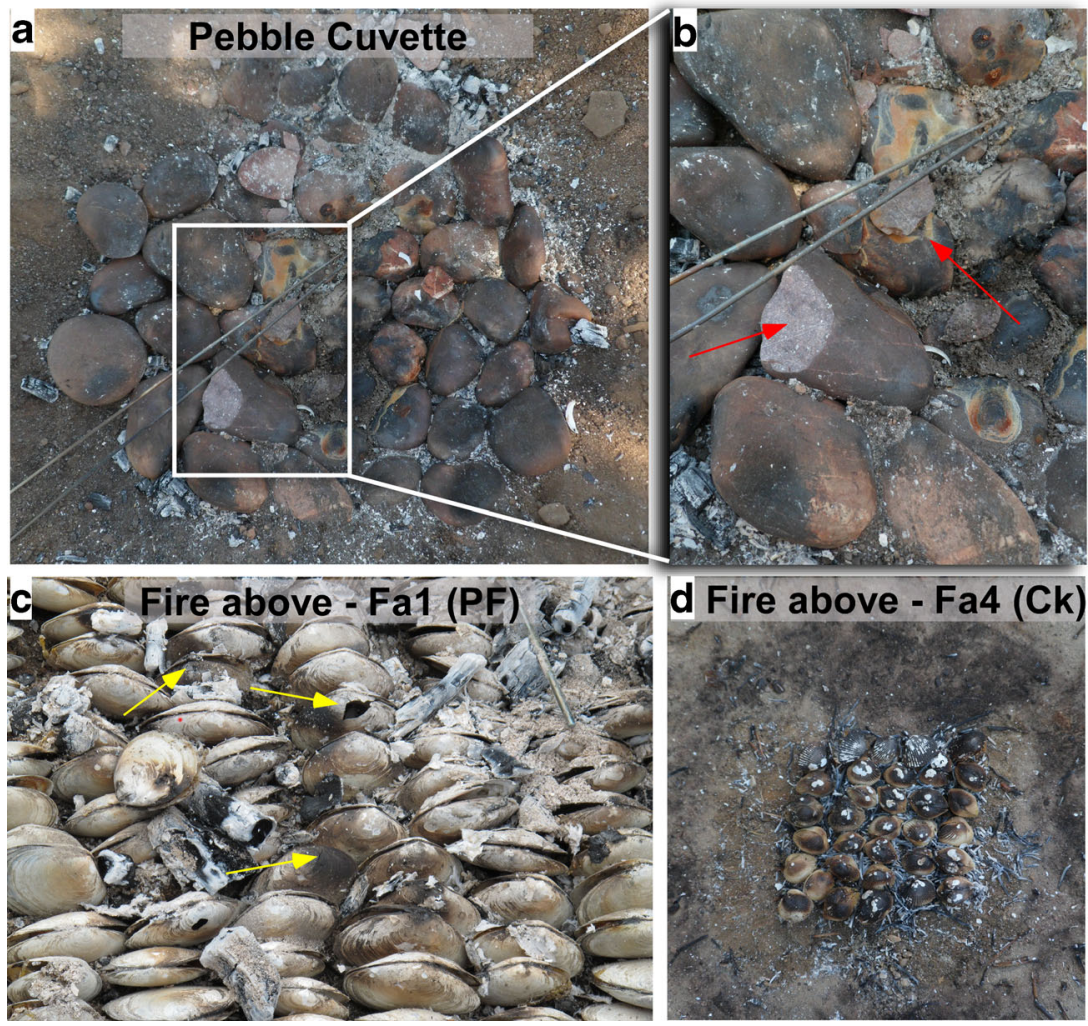

Fig. 5 Macroscopic alteration of pebbles and shells during field cooking experiments: a general and $\mathbf{b}$ detailed view of a pebble cuvette where color modifications and two fire-cracked pebbles are visible (red arrows). Note also the remnants of fire residues between the pebbles (white ashes and charcoals); $\mathbf{c}$ thermal alteration of peppery furrow shells after a fire above experiment fueled with pine wood with darkening of part of the shells and occasional fractures, the latter are preferentially present in the uppermost sections of the shells (yellow arrows); d thermal alteration, namely darkening and some "flaking," of cockle shells after a fire above experiments fueled with pine needles
In high levels of vitrification, the intense alteration observed lead to an almost complete elimination of the original cell morphology. Such levels of vitrification can significantly bias the observation of the cellular structure (e.g., Gale and Cutler 2000; Prior and Alvin 1983; Py and Ancel 2006). Vitrification tends to be more visible and intense in radial and tangential sections. Low to high levels of vitrification were observed on samples from all experiments, with low vitrification levels meaning that vitrification is identified but there was not a substantial damage to the cellular structure. Low levels of vitrification were particularly observed in charcoal fragments from one of the pebble cuvette runs (first repetition of $\mathrm{C} 2(\mathrm{Ck})$ ), though this was not the case for all the pebble cuvette experiments, and therefore probably linked with probability sampling and intrinsic experimental variation. What this data does highlight is that repetitions of the same experimental procedures are very important in actualistic experiments such as the ones commonly performed in experimental archaeology. Finally, the presence of cracks on charcoal is evident in at least one fragment from each experiment. Although this alteration is not as frequent as vitrification, it is still abundant and cracks tend to co-occur in fragments where vitrification is also present.

\section{Roasting shellfish: mineralogy-associated transformations}

The results of the FTIR analysis are summarized in Table 2. Shells analyzed from the pebble cuvette experiments (C1-C3), where the shells did not come into direct contact with the fire, were still composed solely of aragonite. Similar results were consistently obtained from the experiments with fire above using pine embers (Fa5 and $\mathrm{Fa} 6$ ) where the maximum fire temperature was lower than in all other experiments (average of $417{ }^{\circ} \mathrm{C}$, see Table 2), although since this temperature should allow at least partial mineralogical transformation, this result might be due to small sample size.

A more complex picture emerges from the experiments using fire below and fire above with pine wood or needles as fuel, with the mineralogical compositions of the shells varying in a number of these experiments. Several of the analyzed shells retain an aragonite composition, while others are already transformed to calcite. 


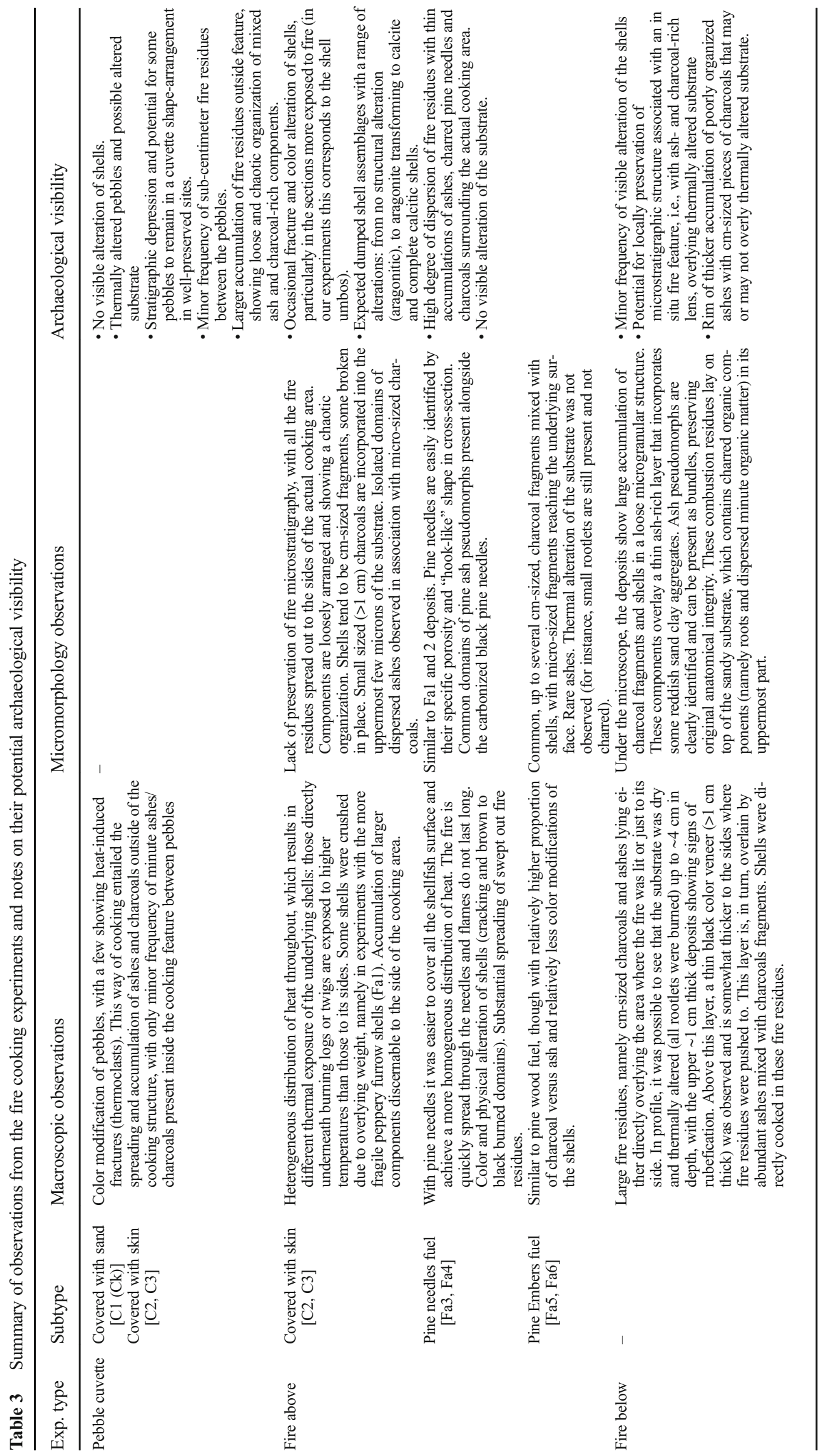



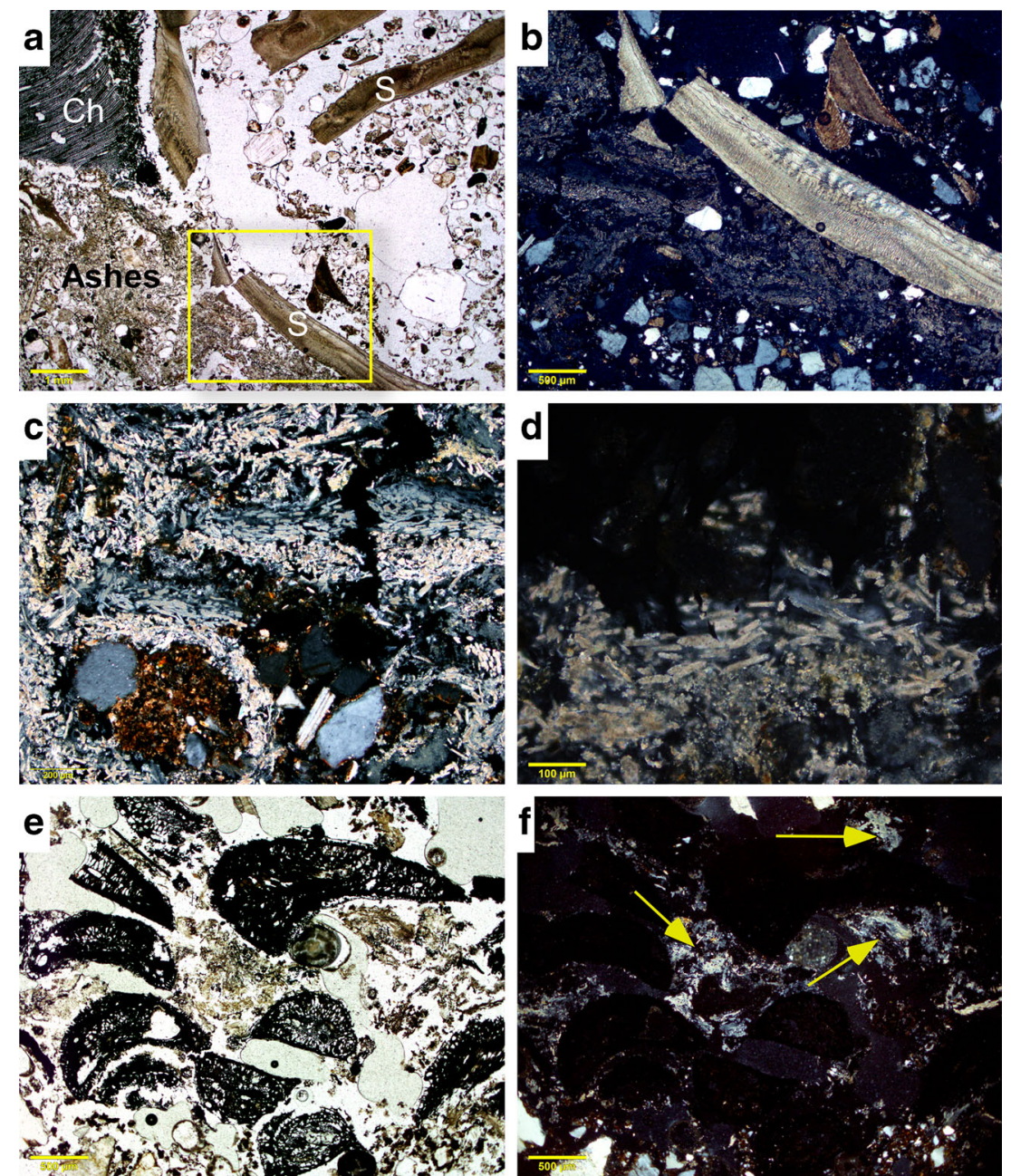

Fig. 6 Photomicrographs of key components and micromorphological features of field cooking experiments: a view of sediments produced in experiment $\mathrm{Fb}$ where it is possible to see the lateral accumulation of ashes, charcoal $(C h)$, and several shell fragments $(S)$, the latter embedded in a loose microgranular structure, in PPL. Scale is $1 \mathrm{~mm}$. b Close-up view of area marked by square in (a) where we can observe the contact between the calcitic ashes and the aragonitic cockle shell, in XPL. Scale is $500 \mu \mathrm{m}$. c Micrograph of pine wood ash with laminated bundles of alternating white and dark gray calcitic pseudomorphs of calcium

It is interesting to note that in experiments $\mathrm{Fa} 2$ and $\mathrm{Fb}$, a few of the analyzed cockle shells have spectra associated with aragonite transforming to calcite, showing that such specimens had to be subject to temperature ranges roughly between 250 and $350{ }^{\circ} \mathrm{C}$, as shown by our controlled muffle heating results discussed above.

\section{Roasting shellfish: what are the microstratigraphic traces?}

In Table 3, we synthesize the macro- and microscopic observations concerning the sedimentary and taphonomic signatures produced during our shellfish roasting experiments.

Of the three types of cooking tested, only the fire below experiment produced a microstratigraphic arrangement typical

oxalate cells mixed with quartz grains and rounded silty clay aggregates, in XPL. Scale is $200 \mu \mathrm{m}$. d Detailed view of rhombic pseudomorphs after calcium oxalate of pine wood cells in anatomical connection, in XPL. Scale is $100 \mu \mathrm{m}$. e Micrograph of fire above experiment Fa3 where pine needles were used as fuel. Note the black hook-shape of the pine needles cross-section and their internal porosity, in PPL. Scale is $500 \mu \mathrm{m}$. f Same as (e) but in XPL. Note the presence of calcitic ash domains around the carbonized pine needles (arrows)

of in situ hearths, that is, a thermally altered substrate overlain by fire residues with abundant charcoals and ashes. For the most part, however, the employed cooking methods involved the partial or complete removal of the majority of fire residues prior to cooking (see Fig. 1). Even in the fire below experiment, part of the embers and ashes were pushed aside in order to create a central area where the shellfish was placed. This action resulted in an external rim with a relatively thicker accumulation of chaotically organized, $\mathrm{cm}$-sized pieces of carbonized wood tissues, ashes, and charcoals. Locally, these deposits may or may not overly altered substrate, depending on how far they were dispersed from the original location. At the center of the hearth, that is, where the shellfish were cooked, the accumulation of fire residues is thinner $(1-2 \mathrm{~cm}$ 
thick), though with some degree of structural organization as seen microscopically by the presence of articulated ashes overlying a thin rubefied substrate (Fig. 6).

In all other experiments, the cooking procedure entailed the removal, spreading, and dumping of fire residues outside the actual cooking area. In the case of the pebble cuvette hearths, the large pieces of carbonized wood and charcoals were removed and the remaining finer fraction blown out in order to exposed the surfaces of the hot pebbles. We could observe that smaller size fractions of ashes and charcoals had accumulated and rested in the spaces between pebbles, namely at the deepest part of the basin-shaped depression (Fig. 5). The actual fire residues were quickly dumped nearby this feature and presented a chaotic organization of large-sized components in a loose, open structure, overlaying a non-altered substrate. The "path" of deposits removal could be traced by the spreading of finer ashes from the pebble feature to the main dumping area. This type of fragile deposits and organization, however, are unlikely to survive archaeologically. The most conspicuous element of this type of cooking is obviously the structuring of the cooking area with the sedimentary depression and arrangement of the pebble cover. During our several repetitions, only a few of the pebbles were thermally fractured, whereas the central pebbles typically showed some type of color modifications, from reddish to black hues (Fig. 5). Although we could not sample these deposits for micromorphology, the temperature readings of the substrate directly underneath the cuvette do show that these deposits reached temperatures between 200 and $300{ }^{\circ} \mathrm{C}$. This type of cooking has, therefore, the potential to produce some thermal alteration of underlying artifacts and sediments (e.g., resetting of thermoluminescence signal, charring of organic matter, rubefication), and such modifications may be identifiable in archaeological contexts (Aldeias et al. 2016; Canti and Linford 2000; Linford and Platzman 2004; March et al. 2014).

One of the most striking aspects of the fire above cooking experiments is the lack of association between the fire, its residues, and the surrounding deposits. These fast fires kindled on top of shellfish were fairly short-lived-otherwise, the mollusk was not cooked but rather burned. Subsequently, all the ashes and charcoals were quickly swept and blown out from the top of the shells and these were removed from their cooking location and consumed. Therefore, in all of our experiments, there is little or no visible macro- or microscopic alteration of the substrate underlying the cooking location. The swept out fire residues tended to be fairly dispersed, namely in the case of the fires fueled with the fragile pine needles. Some thicker accumulation of charcoals and partially carbonized wood pieces overlying unaltered substrates were produced in the pine wood-fueled experiments, namely in those were the fires were not left to burn to completion.

In the thin sections from fire above experiments, there are few diagnostic features, especially if we consider that the shells themselves would have been removed from their cooking arrangement and probably tossed somewhere else after the mollusk was eaten. Therefore, only the discrete presence of charcoals, charred pine needles, and rare domains with calcitic wood ashes indicate the presence of fire activities. In contrast, however, it was during these fire above experiments that significant physical and color modifications were produced in the shells themselves, since these were directly exposed to heat from the superimposing fire. Macroscopically, we could see that quite a few shells tended to have burned black to brown domains, with some of the more fragile peppery furrow shells also showing cracking and fissuring (Fig. 5). These cracks and burning is preferentially located in the uppermost umbos sections, which in our cooking arrangement were positioned upwards and in direct contact with the fires.

\section{Discussion}

\section{Temperature threshold for mineralogical transformation of cockles and peppery furrow shells}

Before discussing the specific effects of temperature on structural modification of $\mathrm{CaCO}_{3}$ polymorphs, our use of both FTIR transmission and ATR collection modes allow us to directly compare and discuss results obtained with these two procedures. As shown in Fig. 3, despite minor shifts in peak positions, we have similar results when using FTIR and FTIR-ATR. Both methods were equally able to detect the process of aragonite transforming to calcite and the complete change to a calcite structure at higher temperatures (Table 1 and Fig. 3). One of the often mentioned shortcomings of FTIR-ATR is that penetration depth increases at lower wavenumbers (Miller 2002), which means that peak intensities at higher wavenumbers are much lower than in transmission spectra affecting absorptions in this region. Despite this effect, however, it is important to observe that the $\mathrm{O}-\mathrm{H}$ stretching vibration of calcium hydroxide $\left(\mathrm{Ca}(\mathrm{OH})_{2}\right)$ at $3640 \mathrm{~cm}^{-1}$ is equally identifiable by both methods in the samples heated to $900{ }^{\circ} \mathrm{C}$ (see supplementary information). When comparing the two methods regarding sample preparation and convenience, the FTIR-ATR procedure is somewhat faster and easier. For both methods, some grinding of the sample is needed, but while this is the only requirement for FTIR-ATR, one should in addition prepare a $\mathrm{KBr}$ pellet for FTIR. Due to 
Table 4 The range of temperatures for complete transformation of aragonite to calcite from different sources

\begin{tabular}{|c|c|c|c|}
\hline \multicolumn{2}{|c|}{ Original material } & \multirow{2}{*}{$\begin{array}{l}\text { Temperature for complete } \\
\text { transformation }\end{array}$} & \multirow{2}{*}{$\begin{array}{l}\text { Reference } \\
\text { Shahack-Gross et al. } 2005\end{array}$} \\
\hline Inorganic & $\begin{array}{l}\text { Kurkar rock (quartz sand grains } \\
\text { and aragonitic mollusk shells } \\
\text { cemented by calcite) }\end{array}$ & & \\
\hline & Hot springs & $400-485^{\circ} \mathrm{C}$ & $\begin{array}{l}\text { Suzuki } 1973 \text { (as cited in } \\
\text { Yoshioka and Kitano } \\
\text { 1985) }\end{array}$ \\
\hline & Inorganic aragonite & $450-470{ }^{\circ} \mathrm{C}$ & Yoshioka and Kitano 1985 \\
\hline \multirow[t]{7}{*}{ Biogenic } & Corals & & \\
\hline & Coral aragonite & $380-400{ }^{\circ} \mathrm{C}$ & Yoshioka and Kitano 1985 \\
\hline & Hexacollara species & $280-320^{\circ} \mathrm{C}$ & $\begin{array}{l}\text { Igarashi } 1969 \text { (as cited in } \\
\text { Yoshioka and Kitano } \\
\text { 1985) }\end{array}$ \\
\hline & \multicolumn{3}{|l|}{ Shells } \\
\hline & Shells aragonite & $380-400{ }^{\circ} \mathrm{C}$ & Yoshioka and Kitano 1985 \\
\hline & $\begin{array}{l}\text { Peppery furrow (Scrapularia } \\
\text { plana) }\end{array}$ & $400^{\circ} \mathrm{C}$ & This paper \\
\hline & Cockles (Cerastoderma edule) & $500^{\circ} \mathrm{C}$ & This paper \\
\hline
\end{tabular}

the $\mathrm{KBr}$ hydrophilic nature, a heat lamp to keep the $\mathrm{KBr}$ dry is also required. Therefore, although the FTIR method is more sensitive at higher wavenumbers, FTIR-ATR collection mode may be easier to operate, especially in humid environments. All these factors should be taken into consideration, especially in archaeological excavations when laboratory techniques can be brought into the field.

Concerning the results from our controlled muffle experiments, infrared analyses revealed that the transformation from aragonite to calcite started around $250{ }^{\circ} \mathrm{C}$ for cockles and at $350{ }^{\circ} \mathrm{C}$ for peppery furrow, with complete transformation occurring around 500 and $450{ }^{\circ} \mathrm{C}$, respectively. These results show that, in the range of temperatures between the start of the transformation until the shell is completely transformed, we should expect various amounts of the two polymorphs - in stages that we designated as "aragonite transforming to calcite" and "calcite with traces of aragonite." This mixed composition is seen in Fig. 3 with the appearance of the calcite $v_{2}$ absorbance band at $876 \mathrm{~cm}^{-1}\left(874 \mathrm{~cm}^{-1}\right.$ in ATR $)$ alongside with the aragonite absorbance band at $860 \mathrm{~cm}^{-1}\left(856 \mathrm{~cm}^{-1}\right.$ in ATR), and the $v_{3}$ absorbance bands at $1427 \mathrm{~cm}^{-1}\left(1405 \mathrm{~cm}^{-1}\right.$ in ATR) overlapping with the aragonite main peak at $1475 \mathrm{~cm}^{-1}$ (1465 $\mathrm{cm}^{-1}$ in ATR), thus resulting in a wider absorption peak in this area.

Previous studies on high temperature aragonite transformation to calcite from biogenic sources (corals and shells) show that biogenic aragonites tend to turn completely calcitic $\sim 400{ }^{\circ} \mathrm{C}$ or even at lower temperatures of $280-320^{\circ} \mathrm{C}$ (see Table 4 and references therein). Conversely, our results show that one of the species studied here (cockles) was exclusively calcitic only at $500{ }^{\circ} \mathrm{C}$, with these structural transformations occurring after merely $5 \mathrm{~min}$ of heating. In general, biogenic aragonite starts transforming at lower temperatures (200 to
$500{ }^{\circ} \mathrm{C}$ ) than geogenic or synthesized inorganic aragonite (Yoshioka and Kitano 1985). It has been suggested that this results from higher incorporated water and organic matter in the lattice of biogenic aragonite, which makes it less stable (Gaffey et al. 1991; Yoshioka and Kitano 1985). Gaffey et al. (1991) also suggested that high amount of lattice defects may be another possible explanation for the lower stability of biogenic aragonite. Varied water content and organic matter were confirmed by our TGA results, where we can observe the relatively higher amount of organic matter in peppery furrow than in cockles (see supplementary information). This difference might help explain the distinct rates and temperature thresholds observed for complete transformation to calcite in these two species.

Overall, the available evidence highlights the diversity of temperature dependent aragonite transformation between different biogenic sources. Although quantitative estimations are difficult to obtain (though see Loftus et al. 2015), an assessment of the relative amounts of aragonite versus calcite may help determine the range of temperatures to which a shell was exposed. We should take into consideration that such mixed compositions (like the transformation stages of "aragonite transforming to calcite" and "calcite with traces of aragonite" obtained in our study) might not preserve in the archaeological record, since pyrogenic and biogenic sources of aragonite and calcite are relatedly disordered at the atomic level and tend to recrystallize as more ordered mineral phase after dissolution (Weiner 2010). In geology, the phenomenon of replacement of aragonite with calcite in high temperature/high pressure conditions (e.g., in carbonate rocks) and the instability of aragonite at surface pressures is well known. However, this type of replacement operates at a larger geological timescale and not generally affecting archaeological associated chronologies. 
Yet, since aragonite is less stable than calcite at ambient temperatures and pressures, it is more soluble and hence more affected by other types of diagenesis which can affect the archaeological record. In general, both $\mathrm{CaCO}_{3}$ polymorphs are relatively soluble, and when dissolved, a more stable phase will precipitate, in the case of the aragonite it would usually be the more stable/ordered calcite (Weiner 2010). The tendency of aragonitic shells to re-precipitate as calcitic in the fossil record can be used as a proxy for accessing the mineralogical preservation state in archaeological sites (Namdar et al. 2011; Weiner et al. 2002). This has special relevance in the use of aragonite $>$ calcite transformation based on biogenic shells as specific temperature proxies for past archaeological fires, or ceramic firing, suggesting that precise studies on temperature thresholds for the analyzed species first need to be attested.

\section{Mineralogical transformations associated with roasting of shells}

When considering the range of temperatures in which aragonite transforms to calcite in the two species studied here (Table 1), together with the temperatures recorded in our fire cooking experiments and the mineralogical composition of the cooked shells (Table 2), the following patterns can be pointed out:

1. In all the pebble cuvette experiments, the cooked shells maintained an aragonitic composition. This is expected since the shells did not come in direct contact with the fire and therefore were exposed to lower temperatures (Fig. 4 and Supplementary Information). Similar results would also be expected in any form of cooking though boiling.

2. In both fire above and fire below experiments, there was some degree of direct contact between the shells and the fire/embers. Therefore, the probabilities of some shells reaching the temperature threshold increase substantially. Accordingly, our results do show that for the majority of these experiments, we had varying degrees of structural changes, from fresh aragonitic shells, to fully calcite and/ or aragonite transforming to calcite. It is important to note that these results occur even though readings from the thermocouple laid on the ground between the shells recorded temperatures that were not high enough to reach the threshold for aragonite to calcite transformation (Table 2). However, given the high values and temperature oscillations of the fire itself, there were locally high enough temperatures to transform at least part of the assemblage, and the positioning of one single thermocouple does not detect these spatial fluctuations. The rapid nature of the cooking events and the patchy contact between the fire and the shells resulted in the identified mixed mineralogical composition in the cooked shells.
These two observations suggest that, when dealing with cooking events in containers, no mineralogical transformation of the shells should be expected. However, any cooking technique that involves direct contact with fire could lead to a mixed assemblage with both aragonitic and calcitic shells regardless of how ephemeral the cooking events were. Therefore, in an archaeological site where the carbonate minerals are well preserved, we would expect to find either aragonitic or both aragonitic and calcitic shells when dealing with assemblages related to cooking activities of similar types of mollusks.

Conversely, in situations where an originally aragonitic shell assemblage shows complete transformation to calcite mineralogy, two possible interpretations can be inferred: either it has been subjected to significant diagenesis, with dissolution of aragonite and calcite recrystallization or it was exposed to high temperatures such as those produced by a hearth. In the latter situation, the maintenance of temperatures high enough to result in the widespread transformation of shells from aragonite to calcite is more consistent with hearths unrelated to cooking. Such complete burning might happen if the shells were thrown into an active fire (Villagran 2014b) or if the shells were part of the substrate underlying a fire, with experimental work estimating that such temperatures can be reached in sediments buried up to $6 \mathrm{~cm}$ in depth (Aldeias et al. 2016). As we have shown, roasting shellfish events are primarily fast fires, and while the temperature of the fires themselves can oscillate between $\sim 400$ and $\sim 900{ }^{\circ} \mathrm{C}$, only locally do temperatures above $400{ }^{\circ} \mathrm{C}$ occur in association with the shellfish being cooked. Overall, much lower temperatures are required; otherwise, the shellfish is burned instead of cooked. This work suggests that we can now separate between mixed mineralogical assemblages, which imply cooking, and completely transformed assemblages, which imply in situ burning (i.e., hearths on top of shell rich matrix) and should be interpreted as fire places rather than shell roasting hearths.

\section{Microstratigraphic signatures of roasting shellfish and their archaeological visibility}

The cooking experiments described above suggest that we should not expect to encounter "well- preserved" combustion features related to similar shell roasting in the archaeological record since part of these cooking procedures involved spreading of fire residues. In fact, some degree of scattering is an essential step of all of the roasting methods presented here, with fuel residues dumped outside the cooking area and largely overlying unburned substrates (Fig. 7). Such spreading and dumping results in either almost invisible cooking events, such as roasting with pine needles (which leaves no trace in the substrate and only fine ashes with weak archaeological preservation) or "disconnected" cooking events in which fire 
Fig. 7 Illustration of the final stages of three main types of roasting shellfish procedures (left), with the annotated plan view showing macroscopic observations of sedimentary and artifact dispersion features and their idealized visibility in profile view (right)

\section{Pebble Cuvette}
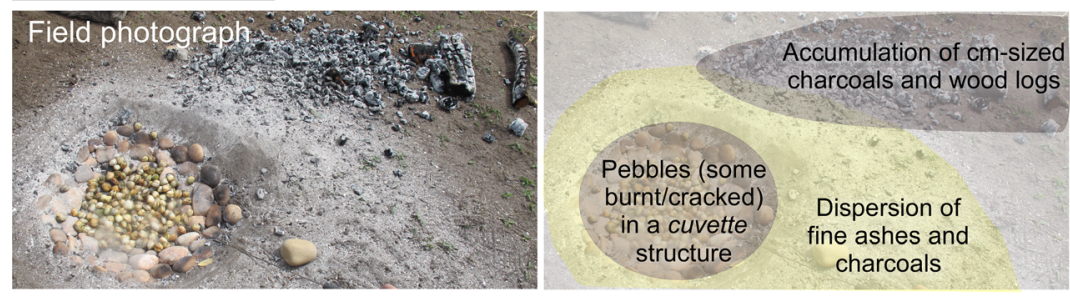

Schematic profile view

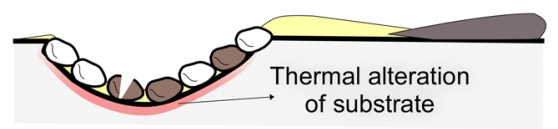

Fire Below
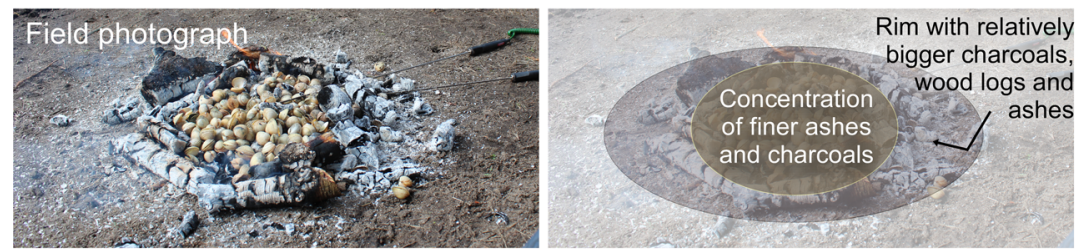

Schematic profile view

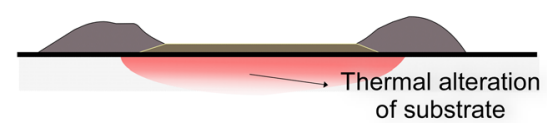

Fire Above
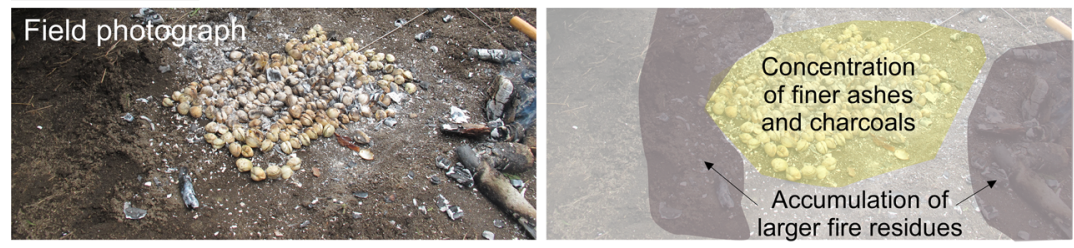

Schematic profile view

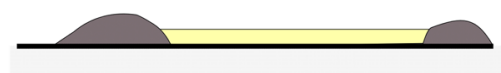

residues are spread outside the actual combustion locus. Only in roasting experiments with fire below could we expect to locally find a microstratigraphic structure resembling in situ hearths, with ashes and charcoals partially overlying thermally altered substrates - for example, with reddened (rubefied) sediments, charred organic matter, or burned clays, depending on fire temperature/duration and composition of the substrate (see Aldeias et al. 2016). However, even in these experiments, the center of the hearth was disturbed by gently scattering of combustion materials. This action resulted in some disruption of the original sedimentary association, creating thicker external rims of unorganized accumulation of ashes and charcoals (Fig. 7). Such mixed deposits can easily be misinterpreted as a disturbed hearth in archaeological contexts, whereas they actually reflect the expected outcome of in place roasting shellfish events. The produced microstratigraphy is distinct from that expected from an in situ, undisturbed hearth (see the experimental hearth reported in Villagran 2014b).

Cooking using earth oven methods, such as our pebble cuvette experiments, would have the highest likelihood of archaeological visibility. Even though fire residues were equally scattered and, if preserved, would be found outside of the cuvettes themselves (Fig. 7), the dug basin and the shattered thermoclasts have higher chances to be found in situ, possibly with ashes and microcharcoals between the pebbles. In optimal preservations, it might be possible to identify the accumulation of dumped combusted material. These sediments have a loose and chaotic organization, with ashes being intrinsically mixed with charcoals and with an absence of associated burned sediments (either underlying it or as pieces of rubefied material mixed with the combusted deposits). Although technically in a secondary position, such accumulations reflect anthropogenically reworking actions and are expected outcomes of cooking roasting fires.

\section{Conclusions and future directions}

Despite increased interest in the role of marine resources in human evolution, our knowledge regarding behavioral traits 
linked to shellfish processing and their visibility in the archaeological record is still limited. Based on ethnographic evidence, it is often assumed that the expediency of shellfish cooking can leave little or no trace on the archaeological record. Furthermore, sediments and shells can also be burned in events unrelated to shellfish cooking activities, for instance if a fire is lit on top of shell-rich matrix, which makes it even harder to identify shell cooking events in the archaeological record (March 1999b; Villagran 2014a). In this paper, we explored microarchaeological signatures produced by experimental roasting shellfish activities in order to improve our ability to identify such events. Our experimental procedure focused both on controlled heat-induced mineralogical transformations of aragonitic shells (cockles and peppery furrow species) and on a series of shellfish roasting fires.

The obtained data showed that initial mineralogical transformations from aragonite to calcite starts already after 5 -min exposures to $250{ }^{\circ} \mathrm{C}$ on cockles and at $350{ }^{\circ} \mathrm{C}$ on peppery furrow shells. Complete transformation to calcite occurs at $500{ }^{\circ} \mathrm{C}$ and at $400{ }^{\circ} \mathrm{C}$ in cockles and peppery furrows, respectively. Visual, macro- and microscopic changes were associated with this transformation with shells of both species presenting distinct calcitic microscopic birefringence, macroscopic crazing, and color transformations related to temperature exposures above $\sim 500{ }^{\circ} \mathrm{C}$. Similar alterations were observed in a small percentage of the experimental roasted shells, specifically when cooked in direct connection with active fires as in experiments fire below and fire above with pine wood and pine needle fuels. These experiments produced an assemblage of mixed mineralogical compositions ranging from pure aragonitic shells to complete transformation to a calcite structure. No mineral transformation was observed in experiments without a direct contact with burning fuel (that is, pebble cuvette type of cooking) or when pine embers were used (probably due to the small sample size tested). Hence, based on these results, the presence of mixed mineralogical assemblages can imply a type of cooking, whereas we would argue that completely transformed assemblages tend to imply in situ secondary burning of shells (i.e., hearths on top of shell rich matrix). The latter should be interpreted as fire places rather than shell roasting events.

Shellfish roasting fires tended to be ephemeral in nature and cooking process involved the removal, spreading, and dumping of combusted materials. These actions largely resulted in the absence of well-preserved microstratigraphies associated with in situ hearths and the creation of anthropogenically reworked deposits of dumped ashes and charcoals overlying sediments not affected by heating. The identification of such deposits in the archaeological record might be associated, therefore, with human behavioral activities and not necessarily with poorly preserved or naturally reworked fire features. Earth oven cooking procedures were tested through our pebble cuvette structures, and these could entail a higher archaeological visibility both through the identification of the dug basin and the presence of thermally altered pebbles. Some degree of thermal alteration of underlying substrate can occur with pebble cuvette and fire below cooking techniques, while such alterations were virtually invisible in the substrates of fire above roasting.

Finally, another important component of roasting fires would be the discard of consumed shells. Once heated, the valves opened, and the mollusks consumed, the cooked shells would have been thrown away, and we could expect that such discarding would entail accumulations of shells. We could expect the accumulation of discrete piles, though it is difficult to envision the preservation of such fragile structures in the archaeological record (with the exception of exceptional preservation conditions). Notwithstanding, the identification of deposits interpreted as discrete tossing events in Mesolithic shell mounds (Aldeias et al. 2016) and ethno historic sites (Balbo et al. 2010; Villagran et al. 2011b) might provide some interesting research avenues for signatures of discarding, especially if such accumulations are investigated for mineralogy and thermal alteration patterns.

By exploring the microstratigraphy and discard signatures associated with shellfish roasting fires, the experiments reported here add to experimentation references contributing to the validation of microstratigraphic observation of archaeological fire features. Future experiments should aim to explore heat-induced transformation of aragonitic shells (due both to cooking and to secondary burning) versus calcite composition derived from diagenesis. Our data suggests that, first, characteristic visual changes of the burnt shells might be of use, and, second, since formation pathways are different, it might be possible to distinguish between the two types of alterations by their level of atomic order (see Regev et al. 2010), but more systematic work on the topic is still needed. In the future, we hope to further test the observations reported here by both continued experimentation on food processing fires and by investigating their applicability on archaeological deposits and features.

Acknowledgments We would like to thank the excavation team of Cabeço da Amoreira, the Museu de Arte Pré-histórica de Mação, and the Cura family for their help with performing the experiments present here. We are grateful to Dr. Filipe Natalio (Martin Luther University Halle Wittenberg, Halle, Germany) for TGA/DSC and XRD measurements and helpful discussion. We appreciate the comments and reviews suggested by Ximena Villagran and an anonymous reviewer to an earlier version of this paper. This research was supported by the Max Planck Society. Open Access funding provided by Max Planck Society. 
Open Access This article is distributed under the terms of the Creative Commons Attribution 4.0 International License (http:// creativecommons.org/licenses/by/4.0/), which permits unrestricted use, distribution, and reproduction in any medium, provided you give appropriate credit to the original author(s) and the source, provide a link to the Creative Commons license, and indicate if changes were made.

\section{References}

Addadi L, Joester D, Nudelman F, Weiner S (2006) Mollusk shell formation: a source of new concepts for understanding biomineralization processes. Chemistry-A European Journal 12:980-987

Aldeias V, Bicho N (2016) Embedded behavior: human activities and the construction of the Mesolithic shellmound of Cabeço da Amoreira (Muge, Portugal). Geoarchaeology 31:530-549

Aldeias V, Dibble HL, Sandgathe D, Goldberg P, McPherron SJ (2016) How heat alters underlying deposits and implications for archaeological fire features: a controlled experiment. J Archaeol Sci 67:64-79

Andersen FA, Brecevic L (1991) Infrared spectra of amorphous and crystalline calcium carbonate. Acta Chem Scand 45:1018-1024

Andersen SH (1989) Norsminde: a "køkkenmødding" with late Mesolithic and early Neolithic occupation. Journal of Danish Archaeology 8:13-40

Andersen SH (2000) 'Køkkenmøddinger'(Shell Middens) in Denmark: a Survey, Proceedings of the Prehistoric Society. Cambridge Univ Press, pp 361-384

Bailey G, Milner N (2002) Coastal hunter-gatherers and social evolution: marginal or central? Before Farming 2002:1-22

Bailey GN, Flemming NC (2008) Archaeology of the continental shelf: marine resources, submerged landscapes and underwater archaeology. Quat Sci Rev 27:2153-2165

Balbo A, Madella M, Godino IB, Álvarez M (2011) Shell midden research: an interdisciplinary agenda for the quaternary and social sciences. Quat Int 239:147-152

Balbo AL, Madella M, Vila A, Estevez J (2010) Micromorphological perspectives on the stratigraphical excavation of shell middens: a first approximation from the ethnohistorical site Tunel VII, Tierra del Fuego (Argentina). Journal of Archaeological Science

Canti M, Linford N (2000) The effects of fire on archaeological soils and sediments: temperature and colour relationships, Proceedingsprehistoric society. The prehistoric society, pp 385-396

Cortés-Sánchez M, Morales-Muñiz A, Simón-Vallejo MD, LozanoFrancisco MC, Vera-Peláez JL, Finlayson C, Rodríguez-Vidal J, Delgado-Huertas A, Jiménez-Espejo FJ, Martínez-Ruiz F, Martínez-Aguirre MA, Pascual-Granged AJ, Bergadà-Zapata MM, Gibaja-Bao JF, Riquelme-Cantal JA, López-Sáez JA, RodrigoGámiz M, Sakai S, Sugisaki S, Finlayson G, Fa DA, Bicho NF (2011) Earliest known use of marine resources by neanderthals. PLoS ONE 6

d'Errico F, Vanhaeren M, Van Niekerk K, Henshilwood CS, Erasmus RM (2013) Assessing the accidental versus deliberate colour modification of shell beads: a case study on perforated Nassarius kraussianus from Blombos Cave Middle Stone Age levels. Archaeometry 51-76

Diniz M, Arias P (2012) O povoamento humano do paleo-estuário do Sado: problemáticas em torno da ocupação dos concheiros mesolíticos, Alterações Ambientais e Interação Humana na Fachada Atlântica Ocidental. APEQ. (IV Jornadas do Quaternário, Dezembro de 2011), Coimbra, pp 139-157

Gaffey SJ, Kolak JJ, Bronnimann CE (1991) Effects of drying, heating, annealing, and roasting on carbonate skeletal material, with geochemical and diagenetic implications. Geochim Cosmochim Acta $55: 1627-1640$
Gale R, Cutler D (2000) Plants in Archaeology Otley. London, Westbury Publishing/Royal Botanic Gardens, Kew

Godino IB, Álvarez M, Balbo A, Zurro D, Madella M, Villagrán X, French C (2011) Towards high-resolution shell midden archaeology: experimental and ethnoarchaeology in Tierra del Fuego (Argentina). Quat Int 239:125-134

Gutiérrez-Zugasti I, Andersen SH, Araújo AC, Dupont C, Milner N, Monge-Soares AM (2011) Shell midden research in Atlantic Europe: state of the art, research problems and perspectives for the future. Quat Int 239:70-85

Habu J, Matsui A, Yamamoto N, Kanno T (2011) Shell midden archaeology in Japan: aquatic food acquisition and long-term change in the Jomon culture. Quat Int 239:19-27

Hardy BL, Moncel MH (2011) Neanderthal use of fish, mammals, birds, starchy plants and wood 125-250,000 years ago. PLoS One 6

Jamieson JC (1953) Phase equilibrium in the system calcite-aragonite. J Chem Phys 21:1385-1390

Johannes W, Puhan D (1971) The calcite-aragonite transition, reinvestigated. Contrib Mineral Petrol 31:28-38

Lafuente B, Downs R, Yang H, Stone N (2015) The power of databases: the RRUFF project. Highlights in Mineralogical Crystallography, ed. T. Armbruster and RM Danisi, W. De Gruyter, Berlin, Germany, pp 1-30

Lin S, Rezek Z, Dibble HL (2016) Experimental design and experimental inference in stone artifact archaeology, In: Collard, M. (Ed.), Lithics, Evolution, Science. Amerind Foundation

Linford N, Platzman E (2004) Estimating the approximate firing temperature of burnt archaeological sediments through an unmixing algorithm applied to hysteresis data. Phys Earth Planet Inter 147:197-207

Llave E, Schönfeld J, Hernández-Molina F, Mulder T, Somoza L, Del Rio VD, Sánchez-Almazo I (2006) High-resolution stratigraphy of the Mediterranean outflow contourite system in the Gulf of Cadiz during the late Pleistocene: the impact of Heinrich events. Mar Geol 227:241-262

Loftus E, Rogers K, Lee-Thorp J (2015) A simple method to establish calcite:aragonite ratios in archaeological mollusc shells. J Quat Sci 30:731-735

Lombardo U, Szabo K, Capriles JM, May JH, Amelung W, Hutterer R, Lehndorff E, Plotzki A, Veit H (2013) Early and middle Holocene hunter-gatherer occupations in Western Amazonia: the hidden shell middens. PLoS ONE 8

Lowenstam HA, Weiner S (1989) On biomineralization. Oxford University Press

March RJ (1999a) Chimie organique appliquee a l'etude des structures de combustion du site de Tunel I. Revue d'Archéométrie 23

March RJ (1999b) Chimie organique appliquée à l'étude des structures de combustion du site de Túnel I. Revue d'archéometrie 23:127-156

March RJ, Lucquin A, Joly D, Ferreri JC, Muhieddine M (2014) Processes of formation and alteration of archaeological fire structures: complexity viewed in the light of experimental approaches. $\mathrm{J}$ Archaeol Method Theory 21:1-45

Marean CW, Bar-Matthews M, Bernatchez J, Fisher E, Goldberg P, Herries AIR, Jacobs Z, Jerardino A, Karkanas P, Minichillo T, Nilssen PJ, Thompson E, Watts I, Williams HM (2007) Early human use of marine resources and pigment in South Africa during the Middle Pleistocene. Nature 449:905-908

McBrearty S, Brooks AS (2000) The revolution that wasn't: a new interpretation of the origin of modern human behavior. J Hum Evol 39: 453-563

McGee WJ, Hewitt JNB (1898) The Seri Indians. US Government Printing Office

Meehan B (1977) Hunters by the seashore. J Hum Evol 6:363-370

Meehan B (1982) Shell bed to shell midden. Australian Institute of Aboriginal Studies, Canberra 
Mentzer S (2014) Microarchaeological approaches to the identification and interpretation of combustion features in prehistoric archaeological sites. J Archaeol Method Theory 21:616-668

Miller LM (2002) Infrared microspectroscopy and imaging. Retrieved in October.

Milner N, Craig OE, Bailey GN (2007) Shell Middens in Atlantic Europe. Oxbow Books Ltd

Namdar D, Zukerman A, Maeir AM, Katz JC, Cabanes D, Trueman C, Shahack-Gross R, Weiner S (2011) The 9th century BCE destruction layer at Tell es-Safi/Gath, Israel: integrating macro- and microarchaeology. J Archaeol Sci 38:3471-3482

Peacock E (2009) An investigation of the common cockle (Cerastoderma edule $(\mathrm{L})$ ): collection practices at the kitchen midden sites of Norsminde and Krabbesholm, Denmark. ACADEMIC PRESS LTD ELSEVIER SCIENCE LTD 24-28 OVAL RD, LONDON NW1 7DX, ENGLAND

Peyroteo Stjerna R (2016) On death in the mesolithic: or the mortuary practices of the last hunter-gatherers of the South-Western Iberian Peninsula, 7th-6th Millennium BCE

Prior J, Alvin K (1983) Structural changes on charring woods of Dichrostachys and Salix from southern Africa. International Association of Wood Anatomists Bulletin 4:197-206

Py V, Ancel B (2006) Archaeological experiments in fire-setting: protocol, fuel and anthracological approach. BAR International Series $\mathrm{S}$, pp 71-82

Regev L, Poduska KM, Addadi L, Weiner S, Boaretto E (2010) Distinguishing between calcites formed by different mechanisms using infrared spectrometry: archaeological applications. J Archaeol Sci 37:3022-3029

Richards MP, Hedges RE (1999) Stable isotope evidence for similarities in the types of marine foods used by Late Mesolithic humans at sites along the Atlantic coast of Europe. J Archaeol Sci 26:717-722

Richards MP, Schulting RJ (2006) Touch not the fish: the MesolithicNeolithic change of diet and its significance. Antiquity 80:444-456

Richards MP, Schulting RJ, Hedges RE (2003) Archaeology: sharp shift in diet at onset of Neolithic. Nature 425:366-366

Sandweiss DH, McInnis H, Burger RL, Cano A, Ojeda B, Paredes R, Sandweiss MadC, Glascock MD (1998) Quebrada Jaguay: early South American maritime adaptations. Science 281:1830-1832

Santos S, Cardoso JF, Borges V, Witbaard R, Luttikhuizen PC, van der Veer HW (2012) Isotopic fractionation between seawater and the shell of Scrobicularia plana (Bivalvia) and its application for age validation. Mar Biol 159:601-611

Shahack-Gross R, Albert R, Gilboa A, Nagar-Hilman O, Sharon I, Weiner S (2005) Geoarchaeology in an urban context: the uses of space in a Phoenician monumental building at Tel Dor (Israel). J Archaeol Sci 32(9):1417-1431

Speth JD (2015) When did humans learn to boil? PaleoAnthropology 54:67

Thoms AV (2008) The fire stones carry: ethnographic records and archaeological expectations for hot-rock cookery in western North America. J Anthropol Archaeol 27:443-460

Toffolo MB, Boaretto E (2014) Nucleation of aragonite upon carbonation of calcium oxide and calcium hydroxide at ambient temperatures and pressures: a new indicator of fire-related human activities. J Archaeol Sci 49:237-248

Villagran XS (2014a) Experimental micromorphology on burnt shells of Anomalocardia brasiliana (Gmelin 1791) (Bivalvia, Veneridae) and its potential for identification of combustion features on ShellMatrix Sites. Geoarchaeology 29:389-396

Villagran XS (2014b) A redefinition of waste: deconstructing shell and fish mound formation among coastal groups of southern Brazil. J Anthropol Archaeol 36:211-227

Villagran XS, Balbo AL, Madella M, Vila A, Estevez J (2011a) Experimental micromorphology in Tierra del Fuego (Argentina): building a reference collection for the study of shell middens in cold climates. J Archaeol Sci 38:588-604

Villagran XS, Balbo AL, Madella M, Vila A, Estevez J (2011b) Stratigraphic and spatial variability in shell middens: microfacies identification at the ethnohistoric site Tunel VII (Tierra del Fuego, Argentina). Archaeol Anthropol Sci 3:357-378

Waselkov GA (1987) Shellfish gathering and shell midden archaeology. Advances in Archaeological Method and Theory 10:93-210

Weiner S (2010) Microarchaeology beyond the visible archaeological record. Cambridge, Cambridge.

Weiner S, Goldberg P, Bar-Yosef O (2002) Three-dimensional distribution of minerals in the sediments of Hayonim Cave, Israel: diagenetic processes and archaeological implications. J Archaeol Sci 29: 1289-1308

Yoshioka S, Kitano Y (1985) Transformation of aragonite to calcite through heating. Geochem J 19:245-249 